\title{
Elements in the 5' Flanking Sequences of the Mouse Low-Affinity NGF Receptor Gene Direct Appropriate CNS, but Not PNS, Expression in Transgenic Mice
}

\author{
Steven L. Carroll, ${ }^{1}$ John B. Schweitzer, ${ }^{3}$ David M. Holtzman, ${ }^{2}$ Michele L. Miller, ${ }^{1}$ Gary M. Sclar, ${ }^{1.2}$ and Jeffrey \\ Milbrandt ${ }^{1}$ \\ 'Division of Laboratory Medicine, Departments of Pathology and Internal Medicine, and ${ }^{2}$ Department of Neurology \\ and Neurosurgery, Washington University School of Medicine, St. Louis, Missouri 63110 and ${ }^{3}$ Division of \\ Neuropathology, Department of Pathology, University of Tennessee-Memphis College of Medicine, Memphis, \\ Tennessee 38163
}

We have initiated a characterization of the cis-acting regulatory elements of the murine low-affinity NGF receptor ( $p 75^{\mathrm{NGFF}}$ ) gene. Despite studies in cultured cells that suggest the p75 ${ }^{\text {NGFr }}$ promoter is constitutive, a detailed analysis of this promoter in five lines of transgenic mice demonstrated a high degree of cell-type specificity: $8.4 \mathrm{~kb}$ of $5^{\prime}$ flanking sequence directs expression of a lacZ reporter to retinal and CNS neurons normally expressing p75 ${ }^{\text {NGFr. A }}$ transgene with 470 bp of $5^{\prime}$ flanking sequence is also expressed in the CNS, but its regulation is aberrant, with a loss of basal forebrain expression. In non-neural tissues, both transgenes were expressed only in the testis, kidney, anterior pituitary, and pancreatic islets; with the exception of the renal pattern of expression, transgene activity was confined to appropriate cells within these tissues. In contrast, although expression of both transgenes was prominent in adrenal medulla and gastrointestinal myenteric neurons, neither construct was active in several sensory or sympathetic ganglia that strongly express the endogenous p $75^{\text {NGFR }}$ gene, indicating that genetic elements necessary for expression in these neurons are not present in these promoter sequences. In addition, neither transgene was activated in Schwann cells during Wallerian degeneration of sciatic nerve. We conclude that regulation of the p75 ${ }^{\text {NGFR }}$ gene is complex, with the first 470 bp of $5^{\prime}$ flanking sequence sufficient for expression in enteric and CNS neurons and additional elements within the first $8.4 \mathrm{~kb}$ of 5 flanking sequence required for restriction to appropriate CNS neurons. Further regulatory elements are possibly required for expression in at least some sensory and sympathetic neurons in the PNS and in Schwann cells. To iden-

Received Sept. 14, 1994; revised Nov. 22, 1994; accepted 1)ec. 5, 1994.

We thank E. M. Johnson, Jr, and R. E. Schmidt for comments and suggestions on the manuscript. This work was supported by grants from the National Cancer Institute (P01 CA49712) and Ronald McDonald Children's Charities. J.M. is an Established Investigator of the American Heart Association $(92001820)$. Support also came from an NIH postdoctoral training grant to S.L.C. (5 T32 D DK07296-12). We thank Robin Wesselschmidt, Pam Goda, and Karen Haag for expert assistance with transgenic mice.

Correspondence should be addressed to Dr. Jeffrey Milbrandt. Department of Pathology and Laboratory Medicine, Box 8118, Washington University School of Medicine, St. Louis, MO 63110

a Present address: Box 33, The Jackson Laboratories, 600 Main Street, Bar Harbor, ME 04609.

Copyright (O) 1995 Society for Neuroscience $0270-6474 / 95 / 153342-15 \$ 05.00 / 0$ tify potential regulatory elements in the $470 \mathrm{bp}$ of $5^{\prime}$ flanking sequence from the smaller transgene, we compared the sequences of equivalent regions from the mouse, rat, and human $\mathrm{p} 75^{\mathrm{NGFR}}$ genes. This "phylogenetic footprint" identified conserved motifs potentially important for the regulation of this gene in the CNS.

[Key words: low-affinity NGF receptor, gene regulation, transgenic mice, neurotrophins, developmental expression, lacZ]

During development, many more neurons are produced than will survive to form the mature nervous system. According to the neurotrophic hypothesis, developing neurons compete for a limited quantity of target-derived neurotrophic factors and only neurons that establish connections with an appropriate target cell avoid programmed cell death. The first neurotrophic molecule identified was nerve growth factor (NGF; Levi-Montalcini, 1987), an important regulatory molecule in the developing PNS. In the PNS, NGF supports the survival of sympathetic (Thoenen and Barde, 1980) and a subset of neural crest-derived sensory (Goedert et al., 1984) neurons during critical developmental periods and may influence the differentiation of these same cells (Macdonnell et al., 1977; Otten et al., 1977; Max et al., 1978; Thoenen and Barde, 1980; Gage et al., 1991). NGF also affects the development and differentiation of several neuronal populations in the CNS (Mobley et al., 1985; Bothwell, 1991a), including notably the intrinsic (Mobley et al., 1985) and projection (Gnahn et al., 1983; Hefti, 1986; Williams et al., 1986) cholinergic neurons of the mammalian striatum and basal forebrain, respectively. NGF belongs to a family of neurotrophins (neuronal survival and differentiation factors) that includes brainderived neurotrophic factor (BDNF; Leibrock et al., 1989), neurotrophin-3 (NT-3; Hohn et al., 1990; Maisonpierre et al., 1990; Rosenthal et al., 1990), and neurotrophin-4/5 (NT-4/5; Hallbook et al., 1991; Berkemeier et al., 1992). Considerable evidence suggests that these other factors promote the survival and differentiation of distinct subpopulations of neurons in a fashion similar to NGF (Barde et al., 1982; Lindsay and Rohrer, 1985; Davies et al., 1986; Hofer and Barde, 1988; Lax et al., 1988; Maisonpierre et al., 1990; Rosenthal et al., 1990).

Two classes of NGF receptor with low $\left(K_{d}=10^{\circ} \mathrm{M}\right)$ and high $\left(K_{d}=10^{-11} \mathrm{M}\right)$ affinity have been identified (Sutter et al., 1979; Landreth and Shooter, 1980; Schecter and Bothwell, 
1981). The biological actions of NGF are believed to be primarily mediated by the high-affinity receptor (Bothwell, 1991b; Meakin and Shooter, 1992), a $135145 \mathrm{kDa}$ integral membrane glycoprotein (Hosang and Shooter, 1985; Radeke and Feinstein, 1991) with tyrosine kinase activity (Kaplan et al., 199lb), which is the product of the trk proto-oncogene (Kaplan et al., 1991a; Klein et al., 1991). The role played by the low-affinity receptor, a 75-80 kDa integral membrane glycoprotein ( $\mathrm{p} 75^{\mathrm{NGFR}}$ ), is less clear (Rodriguez-Tebar et al., 1990; Hempstead et al., 1991; Bothwell, I99 lb; Kaplan et al., 1991a, b; Klein et al., 1991; Lee et al., 1992), as this receptor binds all known neurotrophins with similar affinities (Rodriguez-Tebar ct al., 1990; Squinto ct al., 1991) and may not be expressed by some NGF-responsive neuronal and non-neuronal cells (Holtzman et al., 1992; Pryor et al., 1992). In at least some cell types, however, interaction between $\mathrm{p} 75^{\mathrm{NGit}}$ and trk may be necessary to mediate NGF's effects (Hempstead et al., 1991; Lee et al., 1992; Meakin and Shooter, 1992). Alternatively, $\mathrm{p} 75^{\mathrm{NCFR}}$ may have specialized functions distinct from trk; notably, recent work suggests that p75 NirR may promote neuronal apoptosis (Rabizadeh et al., 1993). Investigations into these disparate possibilities could be facilitated by identifying the genetic elements responsible for regulation of this gene during development and adulthood and using this information to manipulate the expressing cell types.

The human (Chao et al., 1986; Johnson et al., 1986), rat (Radeke et al., 1987), and chicken (Large et al., 1989; Heuer et al., 1990) low-affinity NGF receptor genes have been characterized. Although this has provided useful information on the structure of the protein, the regulation of this locus remains poorly understood (Sehgal et al., 1988; Patil et al., 1990). Previous studies have been interpreted as indicating that the $3 \mathrm{~kb}$ of $5^{\prime}$ flanking sequence adjacent to the transcription initiation sitc of the human p $75^{\mathrm{NC} F \mathrm{R}}$ gene contains a constitutive promoter incapable of directing cell-type-restricted expression in cultured cells (Sehgal et al., 1988; Patil et al., 1990). However, a cosmid containing 8 kb of $5^{\prime}$ flanking sequence, the entire NGF receptor gene and $7.5 \mathrm{~kb}$ of $3^{\prime}$ flanking sequence was appropriately regulated in transgenic mice (Patil et al., 1990). To resolve these apparently contradictory results and identify relevant regulatory sequences, we initiated a characterization of the regulatory elements of the mouse p $75^{\text {sirk }}$ gene. In this article we present an analysis of five lines of transgenic mice in which a lac $Z$ reporter gene is driven by either an extensive region of $5^{\prime}$ flanking sequence ( 8.4 $\mathrm{kb}$ ) expected to perform all genetic functions or a presumptive minimal promoter $(470 \mathrm{hp})$. Contrary to the results obtained in cultured cells, $8.4 \mathrm{~kb}$ of $5^{\prime}$ flanking sequence directs spatially correct transgene expression in the retina, CNS, enteric neurons, adrenal medulla, and several non-neural tissues. A transgene with 470 bp of $5^{\prime}$ flanking sequence also directs expression in CNS neurons, although in an aberrant pattern. Neither construct, however, produces transgene expression in several sensory or sympathetic ganglia that strongly express the endogenous p $75^{\mathrm{N} \text { (iFR }}$ gene nor are they activated in Schwann cells during Wallerian degeneration of the sciatic nerve. We conclude that regulation of the $\mathrm{p} 75^{\mathrm{NGFR}}$ gene is complex, with distinct elements necessary for expression in enteric and CNS neurons and additional elements required for expression in at least some sensory and sympathetic neurons in the PNS and in Schwann cells. Several conserved elements have been identified within this promoter that are candidate regulatory elements.

\section{Materials and Methods}

Isolation and characterization of genomic clones. A rat low-affinity NGF receptor exon I probe was produced by the polymerase chain reaction utilizing rat sciatic nerve cDNA as template and oligonucleotides predicted by the sequence of the rat cDNA (nucleotides 1-24, 152-176; Radeke el al., 1987). This probe was ${ }^{32} \mathrm{P}$-labeled by the random oligonucleotide priming method (Feinberg and Vogelstein, 1984) and hybridized to duplicate filter lifts of $5 \times 10^{5}$ plaques from a $\lambda$ FIX genomic library (Stratagene) under conditions of decreased hybridization stringency $\left(10 \%\right.$ formamide, $2 \times \mathrm{SSC}$ at $42^{\circ} \mathrm{C}$ ); filters were washed in $0.5 \times \mathrm{SSC} / 0.5 \% \mathrm{SDS}$ at $50^{\circ} \mathrm{C}$. Three clones ( $\lambda$ MNR5, $\lambda$ MNR6, $\lambda M N R 7)$ were isolated, and restriction mapping demonstrated these phage to represent overlapping DNA fragments from the same locus. Southern hlots of phage DNA hybridized to the rat exon I probe allowed the identification of a 857 bp BamHI fragment that was subcloned into the $B a m \mathrm{HI}$ site of pGEM-7Zf $(-$ ) (Promega) to produce $\mathrm{p} 7 \mathrm{Bam} 0.7$. Sequence analysis of this subclone demonstrated it to contain exon I of the mouse NGF receptor gene and established the identity and orientation of the genomic clones. Comparison of the first exon sequence to equivalent regions of the rat cDNA (Radeke et al., 1987) demonstrated absolute conservation of the nucleotide and predicted protein sequences within the coding region of this exon with lower, but nonetheless significant, sequence identity in the portion of the exon encoding the mRNA 5 ' untranslated region (data not shown).

The human $\mathrm{p} 75^{\mathrm{N} \text { (itr }} 5^{\prime}$ flanking sequences were isolated from cosmid clone 37-1 (generously provided by Dr. Garrett Brodeur) as a 971 bp Ncol-Sacll fragment and cloned into BSKS $(+)$ (Stratagene) to produce p429-215.

Sequence analysis. Nucleotide sequence was determined from both strands of overlapping deletion clones by the dideoxy chain termination or cycle sequencing methods (Sanger et al., 1977). A portion of these sequences was determined with an automated sequencing machine (ABI model 373A). Sequence assembly was performed using PC/CiENE software (version 6.26, Intelligenetics, Inc.). Differences between our human $\mathrm{p} 75^{\mathrm{NGFR}}$ promoter sequence and the smaller previously published human sequence (Sehgal et al., 1988) may be a consequence of sequence polymorphisms.

Construction of $N G F$ receptor-lacZ transgenes. A $9 \mathrm{~kb} S a l$ fragment from $\lambda$ MNR 5 containing $8.4 \mathrm{~kb}$ of $5^{\prime}$ flanking sequence, exon $\mathrm{I}$, and $\mathrm{a}$ portion of intron I was subcloned into the SalI site of pGEM-5Zf(-) to produce p5Sal8.4. Plasmid p5Sal8.4 was digested with BssHII and polished with DNA polymerase I (Klenow); synthetic 12-mer XhoI linkers (\#1074, New England Biolabs) were then ligated to the unique BssHII site 82 nucleotides $3^{\prime}$ of the transcription initiation site (within the sequence encoding the mRNA $5^{\prime}$ untranslated region). Following digestion with $S a l$ and $X h o l$, this $8.4 \mathrm{~kb}$ fragment was cloned into pBluescript KS (Stratagene) to produce pMMOM8.4. Plasmid pMMOM 8.4 was digested with $X h o l$ and $S a l l$ to release the $8.4 \mathrm{~kb}$ insert, which was then cloned into the Sall site of placF (Mercer et al., 1991) to produce p8.4MNR/ac Z. Plasmid pMMOM8.4 digested with EcoRV was then digested with $X h o l$ and the released fragment cloned into SmaI/SalI-digested placF to produce p470MNRlacZ (470 bp of 5' flanking sequence).

Derivation of transgenic mice. Plasmid DNA was cut with Sall and HindIII for p8.4MNRlacZ and with KpnI and HindIII for p470MNRlac $Z$ to remove vector sequences. Appropriate fragments were separated by electrophoresis through $0.9 \%$ agarose gels and purified by the method of Vogelstein and Gillespie (1979). DNA fragments were diluted to $2.5 \mathrm{ng} / \mu \mathrm{l}$ in $5 \mathrm{~mm}$ Tris $(\mathrm{pH} 7.5) / 0.25 \mathrm{mM}$ EDTA/5 mM $\mathrm{NaCl}$.

DNA was microinjected into the male pronuclei of fertilized eggs from $F_{1}$ lybrid mice $(\mathrm{C} 57 \mathrm{BL} / 6 \times \mathrm{B} 6 \mathrm{C} 3 \mathrm{H}$ ) as described by Hogan et al. (1986). Oocytes surviving microinjection were implanted into the oviducts of pseudopregnant Swiss-Webster foster mothers following established protocol (Hogan et al., 1986). Transgenic founders were identified by polymerase chain reaction using the triple primer system of Zack et al. (1991) and confirmed by Southern blot analysis with a murine protamine- 1 ( $\mathrm{mPl}$ ) probe that recognizes both the endogenous $\mathrm{mPl}$ gene and the $3^{\prime}$ sequences of the lac $Z$ transgenes. Transgene copy number was estimated by comparing the intensity of the $\mathrm{mPl}$ band to that of the transgene. Transgene copy number ranged from 8-10 copies per haploid genome (8.4MNRlacZ line 19) to 15-20 copies (470MNR/acZ line 6). Founder mice were mated to $(\mathrm{C} 57 \mathrm{BL} / 6 \times \mathrm{B} 6 \mathrm{C} 3 \mathrm{H}) \mathrm{F}$, mice to establish transgenic lines.

Histochemical staining of tissues. Adult mice were deeply anesthe- 
tized and perfused transcardially with room temperature phosphate-buffered saline $(\mathrm{pH} 7.3)$ followed by freshly prepared $2 \%$ paraformaldehyde in $1 \times$ PBS $(\mathrm{pH} 7.3)$. Tissues of interest were dissected and postfixed for $60 \mathrm{~min}$ at $4^{\circ} \mathrm{C}$ in $2 \%$ paraformaldehyde in $1 \times \operatorname{PBS}(\mathrm{pH} 7.3)$ Tissues were then transferred to $30 \%$ sucrose in $1 \times$ PBS $(\mathrm{pH} \mathrm{7.3)} \mathrm{and}$ allowed to equilibrate at $4^{\circ} \mathrm{C}$ for $18-24 \mathrm{hr}$. Tissues were then oriented in OCT (Tissue-Tek), frozen on dry ice, and stored at $-70^{\circ} \mathrm{C}^{-1}$ until use

Eight-micrometer sections of the sucrose cryoprotected tissues were cut on a cryostat and thaw-mounted on Superfrost/Plus slides (Fisher Scientific). Bacterial lac $Z$ histochemistry was performed as described by Sanes et al. (1986) in a reaction solution containing $1 \mathrm{mg} / \mathrm{ml} \mathrm{X-gal,}$ $5 \mathrm{~mm}$ potassium ferrocyanide, $5 \mathrm{~mm}$ potassium ferricyanide, $0.02 \%$ NP40, 0.01\% sodium deoxycholate, and $2 \mathrm{~mm}$ magnesium chloride in $1 \times$ PBS $(\mathrm{pH} \mathrm{7.3)}$. After staining for $12-16 \mathrm{hr}$, slides were refixed in $2 \%$ formaldehyde $2 \%$ glutaraldehyde in $1 \times$ PBS $(\mathrm{pH} 7.3$ ) for 24 hr at room temperature. Slides were then either counterstained with $1 \%$ neutral red and mounted or mounted unstained in glycerol-gelatin (Sigma). Slides were examined by light microscopy using standard bright field or Nomarski optics.

Surgical procedures. All animals were cared for and surgical procedures performed in accordance with the guidelines of the NIH Guide for the Care and Use of Laboratory Animals. For unilateral axotomy with prevention of regeneration, the sciatic nerve was exposed in the midgluteal region and transected, with reflection of the distal stump caudally. At appropriate times postaxotomy, animals were taken for lac $Z$ histochemistry as described above.

\section{Results}

Cloning of the mouse p $75^{\mathrm{NCFR}}$ gene and production of transgenic mouse lines

Earlier work (Sehgal et al., 1988; Patil et al., 1990) suggested that regulatory elements directing cell-type-specific expression might be located 3-8 kb upstream of the transcription initiation site of the human $\mathrm{p} 75^{\mathrm{NGFR}}$ gene. To identify potential regulatory elements within comparable regions of the mouse $\mathrm{p} 75^{\mathrm{NGr}}$ gene, lambda clones spanning $14 \mathrm{~kb}$ of 5 ' flanking sequence and the first exon were isolated and characterized (see Materials and Methods for details). A deletion series with $8.4 \mathrm{~kb}$ to $235 \mathrm{bp}$ of $5^{\prime}$ Hanking sequence driving a luciferase reporter was constructed and introduced into p $75^{\mathrm{NG}+\mathrm{K}}$-expressing neuronal ( $\mathrm{PC} 12$ pheochromocytoma) and glial (JS1 schwannoma) cell lines and three nonexpressing cell lines (NIH 3T3 fibroblasts, K562 erythroleukemia cells, PEER T cell lymphoma cells). In agreement with previous work (Sehgal et al., 1988; Patil et al., 1990), we found high levels of reporter expression in all cell lines except PEER cells; expression was not appropriately cell-type restricted even when extensive portions of $5^{\prime}$ flanking sequence were included (data not shown).

Although our initial experiments suggested that the promoter regions we had tested contained only a constitutive promoter, we were aware of instances in which promoters that were inappropriately expressed in cultured cells were properly regulated when introduced into the germline of mice (Dente et al., 1988; Zimmerman et al., 1990). We therefore decided to examine the regulatory capabilities of these sequences in transgenic mice. To compare the regulation conferred by an extensive portion of $5^{\prime}$ flanking sequence $(8.4 \mathrm{~kb})$ to that directed by a presumptive minimal promoter $\left(470 \mathrm{bp}\right.$ ), two $\mathrm{p} 75^{\mathrm{NcirR}}-$ lac $Z$ fusion genes were constructed that contained either $8.4 \mathrm{~kb}$ or $470 \mathrm{bp} 5^{\prime}$ of the p75 ${ }^{\text {Nik }}$ transcription start (Patil et al., 1990) fused to the $E$. coli lacZ gene in placF (Zack et al., 1991; see Materials and Methods for details). These plasmids, known as p8.4MNRlac $Z$ and p470MNRlac $Z$, respectively, were used to produce transgenic mice. Four 8.4MNRlacZ and nine 470MNRlacZ founders were identified and back-crossed to wild-type mates to produce $F_{1}$ offspring. Analyses of transgene activity by histochemical stains with $\mathrm{X}$-gal or a monoclonal antibody directed against $E$. coli $\beta$-galactosidase were performed on 4-week- to 4-month-old transgenic mice and nontransgenic littermates from $F_{1}$ and subsequent generations. Bacterial $\beta$-galactosidase expression was detectable in multiple lines produced from each construct and was similarly distributed in these lines. After an initial survey of transgene expression in all available lines, two representative lines of mice carrying the $8.4 \mathrm{MNR} l a c Z$ transgene and three representative lines carrying the $470 \mathrm{MNR}$ lac $Z$ transgene were selected for extensive analysis and histochemical mapping.

\section{Transgene expression in the CNS}

Prominent lac $Z$ activity was present in the retina and brain of all 8.4MNRlac $Z$ and 470MNRlacZ lines examined. The majority of the cells expressing the transgene were neurons, and staining of these cells, as elsewhere in the body, consisted of one or two punctate areas of staining that was typically juxtanuclcar (Fig. $1 A$ ). In some lines with a high level of expression, however, staining was also present in the projections of the positive neurons (e.g., stratum moleculare of the hippocampus; data not shown); this localization was confirmed by careful examination of counterstained sections that consistently showed an absence of lacZ staining in glial cells. LacZ activity was also noted in subpopulations of ependymal cells lining the olfactory ventricles, the lateral recesses of the lateral ventricles, and the inferior portion of the third ventricle, particularly in the $470 \mathrm{MNR}$ lac $Z$ lines (Fig. 1B, Table 1); these findings are consistent with the results of several previous immunohistochemical mapping studies (Koh et al., 1989; Yan and Johnson, 1989).

Prominent $\mathrm{p} 75^{\mathrm{NGrR}}$ immunoreactivity has been found in multiple locations in the brain including the olfactory bulbs (Koh et al., 1989; Yan and Johnson, 1989), basal forebrain cholinergic nuclei (Hefti et al., 1986; Springer et al., 1987; Koh et al., 1989; Yan and Johnson, 1989), some hypothalamic nuclei (Yan and Johnson, 1989; Pioro and Cuello, 1990a), and the cerebellum (Koh et al., 1989; Yan and Johnson, 1989), with lesser degrees of staining found in other structures such as the cortex (Koh and Loy, 1989; Pioro and Cuello, 1990a), striatum (Koh et al., 1989), and hippocampus (Yan and Johnson, 1989; Pioro and Cuello, 1990a). Prior in situ hybridization studies demonstrated expression of the $\mathrm{p} 75^{\mathrm{NGH}}$ gene to be somewhat more restricted (Koh et al., 1989), suggesting that much (although not all) of the immunoreactivity in areas such as the olfactory bulbs, neocortex, and striatum is produced by projections from $\mathrm{p} 75^{\mathrm{NiFR}}$-expressing neurons. To determine how closely the pattern of transgene expression in our five transgenic lines recapitulated the transcription of the endogenous gene, serial sections through the brains of transgenic mice were prepared and stained for lac $Z$ activity. Transgene expression was thoroughly mapped in $8.4 \mathrm{MNRlac} Z$ line 2 and $470 \mathrm{MNR}$ lac $Z$ line 11 mice, and areas found to be positive in these mice were then examined in the remaining three lines. We concentrated our efforts on the structures of the olfactory system, telencephalon, diencephalon, and cerebellum as these areas have been most extensively studied in previous work and therefore provide the most reliable descriptions of the expression of the endogenous $\mathrm{p} 75^{\mathrm{N} \text { iFR }}$ gene.

Neuronal expression in the brains of mice from the 8.4MNRlacZ lineages was confined to specific structures. We found that, in general, the pattern of expression of the 8.4MNRlac $Z$ transgene recapitulated that of the endogenous gene (Table 1) and was readily detectable in structures such as olfactory bulb (Fig. 1C), the basal forebrain (Fig. 1D), and spe- 

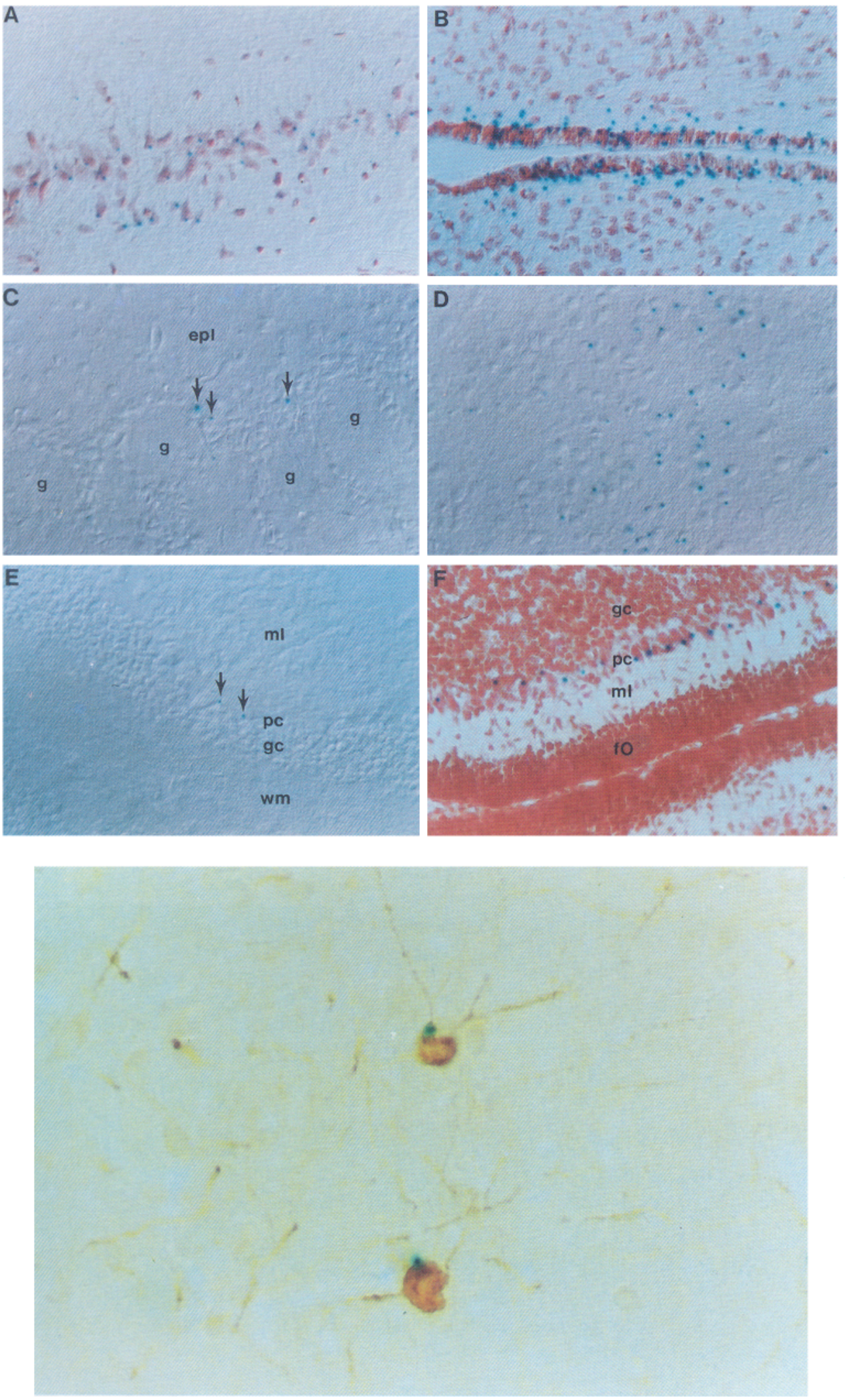

Figure 1. Patterns of $\mathrm{p}^{\text {NGFR }}-\mathrm{lac} Z$ transgene expression in the $\mathrm{CNS}$ of transgenic mice. $A$, typical pattern of neuronal lac $Z$ activity in hippocampal region $\mathrm{CA} 3$ of a $470 \mathrm{MNR}$ lac $Z$ transgenic mouse (line 11). In these neurons, as in all cell types expressing the p $75^{\mathrm{NGFR}}$ $l a c Z$ transgenes, lac $Z$ activity was detected as punctate juxtanuclear areas of blue-green staining. The amount of hippocampal staining seen with this transgene is much higher than that observed in either of the 8.4MNRlacZ lineages, which had only rare lacZ-positive neurons in this structure. This section has been lightly counterstained with neutral red and visualized with Nomarski optics to demonstrate neuronal morphology. $B$, Transgene expression in ependy$\mathrm{mal} / \mathrm{subependymal}$ cells in the ventral portion of the third ventricle from a 470MNRlacZ mouse (dorsal, left; ventral, right). Similar staining was found in the lateral recesses of the lateral ventricles and in the olfactory ventricles. $C$, Section from the olfactory bulb of an 8.4MNRlac $Z$ mouse. Bacterial $\beta$-galactosidase activity was detected in a subpopulation of periglomerular cells ( $a r$ rows) surrounding the glomeruli $(g)$ throughout the olfactory bulb. epl, external plexiform layer. $D, L a c Z$ expression by neurons in the vertical limb of the diagonal band of Broca (8.4MNRlacZ line 2). E, Section from the cerebellum of a 4-month-old (adult) 8.4MNRlacZ line 2 mouse. Although a pair of lightly lacZ-positive Purkinje cells are present in this field (arrows), transgene activity was undetectable in most of these cells even when serial sections through a specific area were examined. Relatively more Purkinje cells were noted to be positive in the vermis. $F$, Section through the cerebellum of a postnatal day $88.4 \mathrm{MNRlacZ}$ line 2 pup. Consistent with previous reports of higher levels of p75 NGFR mRNA in Purkinje cells during the first 2 postnatal weeks, transgene expression is almost universal in Purkinje cells from these younger animals. For $E$ and $F: g c$, granular cell layer; $p c$, Purkinje cell layer; $m l$, molecular layer; $w m$, white matter; $f O$, fetal layer of Obersteiner.

Figure 2. Coexpression of native p75 ${ }^{\text {NGFR }}$ and bacterial lac $Z$ activity. Shown is a $100 \mu \mathrm{m}$ vibratome section of the basal forebrain of an 8.4MNRlac Z mouse histochemically stained for bacterial lacZ activity (the juxtanuclear punctate blue staining) and immunohistochemically stained with a rabbit polyclonal antibody directed against the extracellular domain of $\mathrm{p} 75^{\mathrm{NGFR}}$ (the brown stain marking the neuronal cell body as well as adjacent neuronal processes). In the basal forebrain, as well as in other CNS regions, transgene expression colocalized with immunohistochemically detectable p $75^{\mathrm{NGFR}}$. 


\begin{tabular}{|c|c|c|c|}
\hline CNS region & $8.4 \mathrm{MNR} / 2$ & $470 \mathrm{MNR} / 11$ & References \\
\hline \multicolumn{4}{|l|}{ Basal forebrain } \\
\hline Horizontal limb, diag. band & 1 & & $b, c, d$ \\
\hline Lateral septal nucleus & + & + & 1 \\
\hline Magnocellutar basal nuc. & + & - & $b, c, d$ \\
\hline Magnocellular preoptic nuc. & + & - & $b, c, d$ \\
\hline Medial septal nuc. & + & - & $b, c ; d$ \\
\hline Olfactory tubercle & + & + & $b$ \\
\hline Substantia innominata & + & - & $b, c$ \\
\hline Ventral pallidum & + & - & $b$ \\
\hline Vertical limb, diag. band & + & - & $b, c, d$ \\
\hline Caudate-putamen & rare + & rare + & $b, c$ \\
\hline \multicolumn{4}{|l|}{ Cerebellum } \\
\hline Purkinje cell layer & rare + (adult) & rare + & $a, c, e, f$ \\
\hline Granular cell layer & - & - & $c, e, f$ \\
\hline \multicolumn{4}{|l|}{ Cortex } \\
\hline Neocortex & $+($ rare; $V)$ & $+(\mathrm{I}, \mathrm{II}, \mathrm{V})$ & 1 \\
\hline Ependyma & + & + & $a$ \\
\hline Globus pallidus & $+(\operatorname{rarc})$ & $+1-$ & $b, c, d$ \\
\hline \multicolumn{4}{|l|}{ Hippocampus } \\
\hline Dentate gyrus & + (rare) & $+($ rare $)$ & 1 \\
\hline CA4 & - & + & $b$ \\
\hline CA3 & $+($ rare $)$ & + & $b$ \\
\hline $\mathrm{CA} 2$ & - & - & $b$ \\
\hline CAl & - & + (rare) & $b$ \\
\hline \multicolumn{4}{|l|}{ Hypothalanus } \\
\hline Arcuate nuc. & + & + & $b$ \\
\hline Dorsomedial nuc., diffuse & + & + & $b$ \\
\hline Lateral & + & + & $b$ \\
\hline Medial preoptic area & + & + & $b$ \\
\hline Periventricular nuc. & + & + & $b$ \\
\hline Suprachiasmatic nuc. & - & - & $c$ \\
\hline Supraoptic nuc. & + & + & I \\
\hline \multicolumn{4}{|l|}{ Olfactory bulb } \\
\hline Glomerular layer & + & + & $c$ \\
\hline Mitral cell layer & + & + & $b$ \\
\hline
\end{tabular}

$a$, Yan and Johnson (1989); b, Pioro and Cuello (1990a); $c$, Koh et al. (1989); $d$, Springer et al. (1987); $e$, Pioro and Cuello (1990b); $f$. Wanaka and Johnson (1990).

cific hypothalamic nuclei (Table 1). Double-label immunohistochemistry with a mouse monoclonal antibody specific for bacterial $\beta$-galactosidase (courtesy of $\mathbf{J}$. Sanes) and either a chicken (courtesy of E. M. Johnson, Jr.) or rabbit (Weskamp and Reichardt, 1991) polyclonal serum directed against $\mathrm{p} 75^{\mathrm{NGFR}}$ confirmed that transgene expression in the basal forebrain (Fig. 2) as well as in other CNS strucfures was localized to $\mathrm{p} 75^{\mathrm{NGFR}}$ expressing neurons. Lower levels of transgene expression were noted in other structures where staining was confined to specific subpopulations previously reported to express $\mathrm{p} 75^{\mathrm{NGFR}}$ (e.g., very rare small neurons in the caudate-putamen; Koh et al., 1989; Pioro and Cuello, 1990a). Structures in which p75 sion was believed to be primarily due to the presence of immunoreactive projections from other areas of the brain showed very little evidence of transgene activity. We did, however, note low levels of expression in some neuronal populations not previously reported to express $\mathrm{p} 75^{\mathrm{NGiFR}}$ such as the supraoptic nucleus, lateral septal nucleus (Table 1), and rare neurons in lamina $\mathrm{V}$ of the neocortex (see below). Although we did not map expression in the brainstem as rigorously as we did in the higher structures, we again noted expression was confined to specific nuclei (e.g., prepositus hypoglossal nucleus, interpeduncular nucleus, vestibulocochlear nucleus) known to express $\mathrm{p} 75^{\mathrm{NGFR}}$ protein or mRNA (Koh et al., 1989; Pioro and Cuello, 1990b).

In addition to the basal forebrain, the Purkinje neurons of the cerebellum have been extensively studied as a site of $\mathrm{p} 75^{\mathrm{NGFR}}$ expression. Only rare $l a c Z$-positive Purkinje cells were found in the cerebellum of adult (4-month-old) mice from the 8.4MNRlacZ lines (Fig. $1 E$ ). It is, however, well established that expression of the $\mathrm{p} 75^{\mathrm{NGFR}}$ gene is developmentally regulated in Purkinje cells, with high levels of $\mathrm{p} 75^{\mathrm{NGFR}} \mathrm{mRNA}$ being found only in the first 2 postnatal weeks in the rat (Wanaka and Johnson, 1990; Friedman et al., 1991). We therefore examined transgene activity in the cerebellum of postnatal day 8 mice from 8.4MNRlacZ line 2. Unlike the Purkinje cells of the adult, the majority of these neurons in younger mice were $l a c Z$ positive (Fig. $1 F$ ); in accordance with the in situ hybridization mapping studies of Friedman et al. (1991), transgene expression was not seen in the external granular or other cerebellar layers. These results suggest that in the cerebellum, the $8.4 \mathrm{MNR} l a c Z$ trans- 

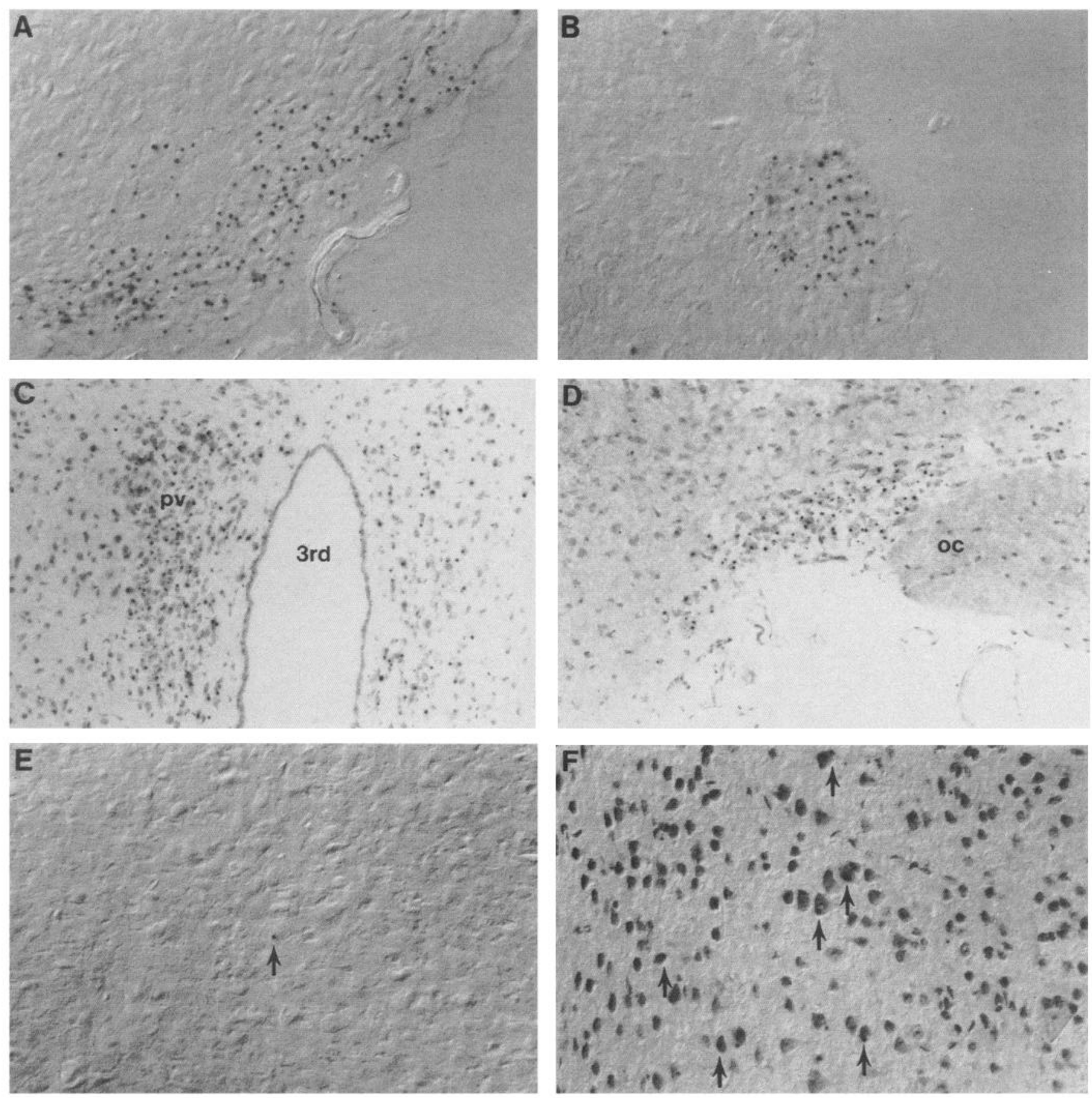

Figure 3. Transgene expression in specific CNS structures. A. Section through the basal forebrain of a $470 \mathrm{MNR}$ lacZ line 11 mouse showing neuronal transgene expression in the olfactory tubercle. This section has not been counterstained and is visualized with Nomarski optics. $B$, LacZ expression in an island of Calleja; this section is from a 470MNRlacZ mouse. $C$ and $D, L a c Z$ activity in the paraventricular $(C)$ and supraoptic (D) nuclei of a $470 \mathrm{MNR}$ lac $Z$ line 11 mouse. Note that the plane of section in $C$ is slightly skewed so that the left paraventricular nucleus is more completely visualized than the right. Localization of transgene activity in the hypothalamus of mice from this line was confined to the same structures that were lacZ positive in the 8.4MNRlacZ lineages. For $C$ and $D: 3 r d$, third ventricle; $p v$, paraventricular nucleus; $o c$, optic chiasm. $E$ and $F$, Coronal sections through the parietal somatosensory cortex of $8.4 \mathrm{MNR} l a c Z$ line $2(E)$ and $470 \mathrm{MNR} l a c Z$ line $11(F)$ mice. Only rare positive neurons are present in the deeper cortical laminae of the $8.4 \mathrm{MNR} l a c Z$ animal $(E$, arrow). LacZ-expressing neurons are present in relatively larger numbers in the $470 \mathrm{MNR}$ lac $Z$ animals $(F$, arrows). Some variation in the number of transgene-expressing cells was noted between different cortical regions with the highest levels noted in the frontal (olfactory) cortex.

gene is appropriately expressed and recapitulates the developmental pattern of expression of the endogenous p $75^{\mathrm{NGFR}}$ gene.

Although we expected the $470 \mathrm{MNR}$ lacZ transgene to contain a minimal promoter capable only of directing constitutive expression, this was not the case. Expression of the 470MNRlacZ transgene, like that of the $8.4 \mathrm{MNR}$ lac $Z$ transgene, was confined to specific structures in the CNS (Fig. $3 A-D$ ). An examination of the same structures studied in the 8.4MNRlacZ mice, however, showed that the pattern of expression of the 470MNRlacZ transgene differed from that of the 8.4MNRlac $Z$ construct (Table 

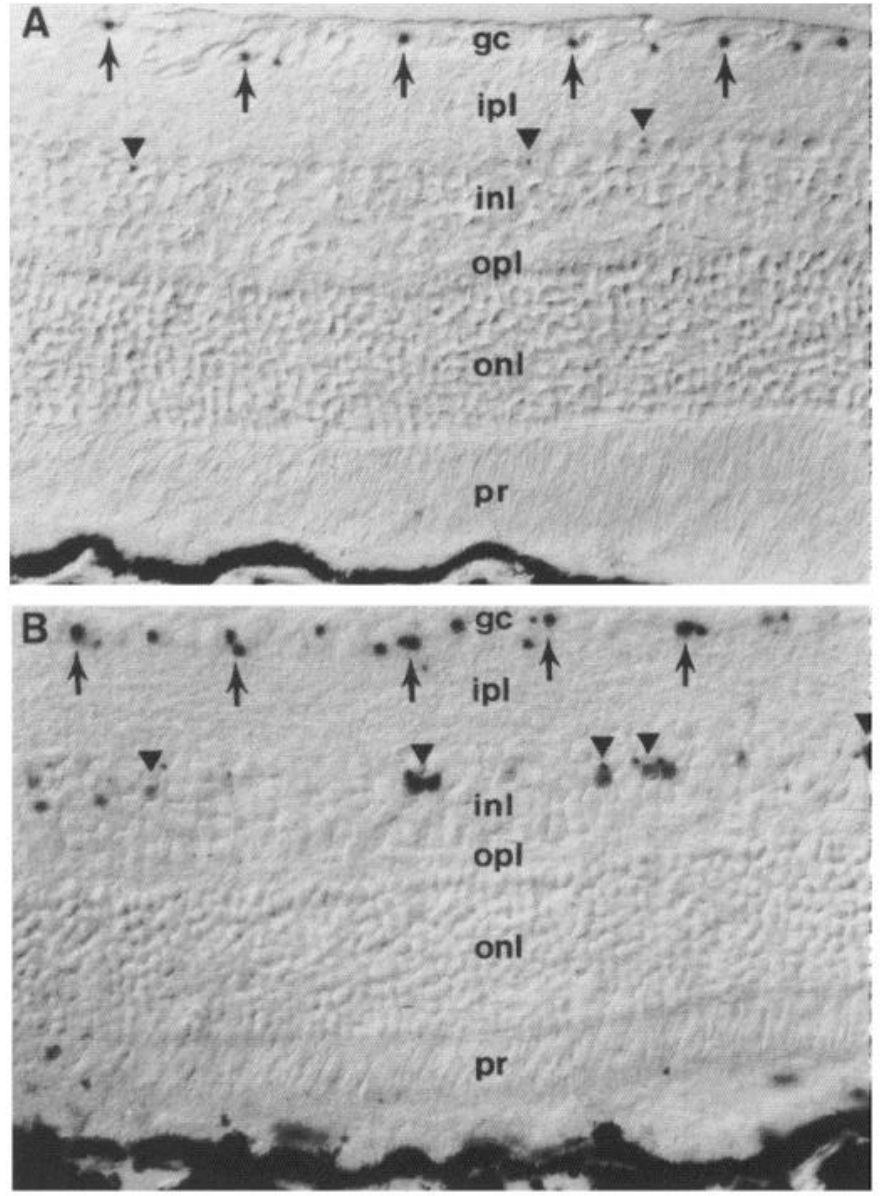

Figure 4. Transgene expression in the retina. A, Section of the neural retina from an adult 8.4MNRlacZ mouse. Prominent $l a c Z$ staining is in a subpopulation of cells in the ganglion cell layer (arrows), faint staining is also seen in scattered cells in the vitread portion of the inner nuclear layer (arrowheads). $B$, Section of the neural retina from an adult 470MNRlacZ line 6 mouse. The distribution of transgene expression in these mice, although more intense, was identical to that seen in 8.4MNRlacZ lineages. Arrows, transgene expression in ganglion cell layer; arrowheads, lac $Z$ activity in the inner nuclear layer. For $A$ and $B$ : $g c$, ganglion cell layer; $i p l$, inner plexiform layer; inl, inner nuclear layer; $o p l$, outer plexiform layer; onl, outer nuclear layer; $p r$, photoreceptors (rods and cones).

1). Particularly notable was a lack of transgene activity in regions of the basal forebrain. In addition, $l a c Z$ activity in the neocortex and hippocampus of the 470MNRlac $Z$ mice was much more prominent than that seen in $8.4 \mathrm{MNR}$ lac $Z$ mice (compare Fig. $3 E, F)$. Although regulatory elements capable of directing appropriate CNS expression must be present in the first $470 \mathrm{bp}$ of the mouse p $75^{\mathrm{NGFR}}$ promoter, their activity is apparently modified by additional regulatory elements contained within the 8.4MNRlacZ transgene and upstream of the first 470 bp of $5^{\prime}$ flanking sequence.

We next examined the eyes of transgenic animals to determine whether transgene expression in the neural retina recapitulated that of the endogenous gene. The retinas of mice from both 8.4MNRlacZ and 470MNRlacZ lineages contained readily detectable subpopulations of lacZ-expressing neurons in the ganglion cell layer (Fig. 4A,B, arrows) and a lesser degree of histochemical staining of some cells within the vitread side of the inner nuclear layer (Fig. 4A,B, arrowheads); no lacZ activity was de-
Table 2. Transgene expression in the PNS of $\mathrm{p}^{75^{\mathrm{NGFR}}-l a c Z}$ transgenic mice

\begin{tabular}{lll} 
Neuron population & $\begin{array}{l}8.4 \mathrm{MNRlacZ} \\
\text { lines }\end{array}$ & $\begin{array}{l}470 \mathrm{MNRlacZ} \\
\text { lines }\end{array}$ \\
\hline $\begin{array}{l}\text { Adrenal medulla } \\
\text { Coeliac ganglion }\end{array}$ & + & + \\
$\begin{array}{l}\text { Dorsal root ganglia } \\
\text { Cervical }\end{array}$ & Very rare + & Very rare + \\
$\quad$ Lumbar & Very rare + & Very rare + \\
Nodose & Very rare + & Very rare + \\
Superior cervical ganglion & - & - \\
Superior mesenteric ganglion & Very rare + & Very rare + \\
Trigeminal ganglion & Very rare + & Very rare + \\
& Very rare + & Very rare + \\
\hline
\end{tabular}

tectable in the outer nuclear layer. Muller glia express p75 (Carmignoto et al., 1991) and the somata of these cells are located in the inner nuclear layer (Drager et al., 1984). It therefore seems likely that the lacZ-positive cells seen in this layer are Muller glia. This overall pattern of retinal expression is consistent with that reported by Carmignoto et al. (1991) in the adult rat retina, indicating that the first $470 \mathrm{bp}$ of $5^{\prime}$ flanking sequence is sufficient to direct spatially correct expression in the neural retina.

\section{Transgene expression in the PNS}

The sensory and sympathetic ganglia of the PNS are classic sites of NGF action (Thoenen and Barde, 1980; Goedert et al., 1984) and expression of $\mathrm{p} 75^{\mathrm{NGFR}}$ has been described in numerous neurons in these structures (reviewed in Bothwell, 1991a), including some that are apparently unresponsive to NGF (Loeb et al., 1992). We found, however, that neither transgene was expressed in many sensory [cervical and lumbar dorsal root ganglia (DRG), nodose and trigeminal ganglia] or sympathetic [superior cervical (SCG), superior mesenteric (SMG), and coeliac ganglia] neurons of the PNS (Table 2, Fig. 5A-C); the single exception was the adrenal medulla, which was intensely positive in all five lines (Fig. $5 D$ ).

To confirm the lack of transgene expression, we analyzed serial $8 \mu \mathrm{m}$ sections through lumbar DRG from our transgenic mice. We found only rare (one to six neurons/ganglion) lacZpositive neurons in DRG from both $8.4 \mathrm{MNRlacZ}$ and 470MNRlacZ lineages (Fig. 5C). In rats, 75-80\% of DRG neurons have been found to express p75 ${ }^{\mathrm{NGFR}}$ mRNA (Carroll et al., 1992) and thus it seems apparent that the number of transgeneexpressing neurons observed in the DRG of these mice falls far below the expected number. Although similar systematic analyses of the number of $\mathrm{p} 75^{\mathrm{NGFR}}$-expressing neurons in the other ganglia examined in this study have not been performed, multiple neurons expressing p75 ${ }^{\mathrm{NGFR}}$ mRNA can be demonstrated in single sections of the superior cervical, superior mesenteric, and coeliac ganglia (M. L. Miller and S. L. Carroll, unpublished observations). It therefore seems likely that only a few of the p75 ${ }^{\text {NGFR }}$-expressing neurons in these ganglia express either of the transgenes.

Although we observed only minimal $l a c Z$ activity in sensory and sympathetic ganglia, a subpopulation of myenteric neurons throughout the digestive system were intensely $l a c Z$ positive in both 8.4MNRlacZ (Fig. 5E) and 470MNRlacZ (Fig. 5F) lineages. We conclude that regulation of the p75 ${ }^{\text {NGFR }}$ locus in myenteric neurons and the adrenal medulla uses elements distinct from those utilized by most PNS sensory and sympathetic neu- 

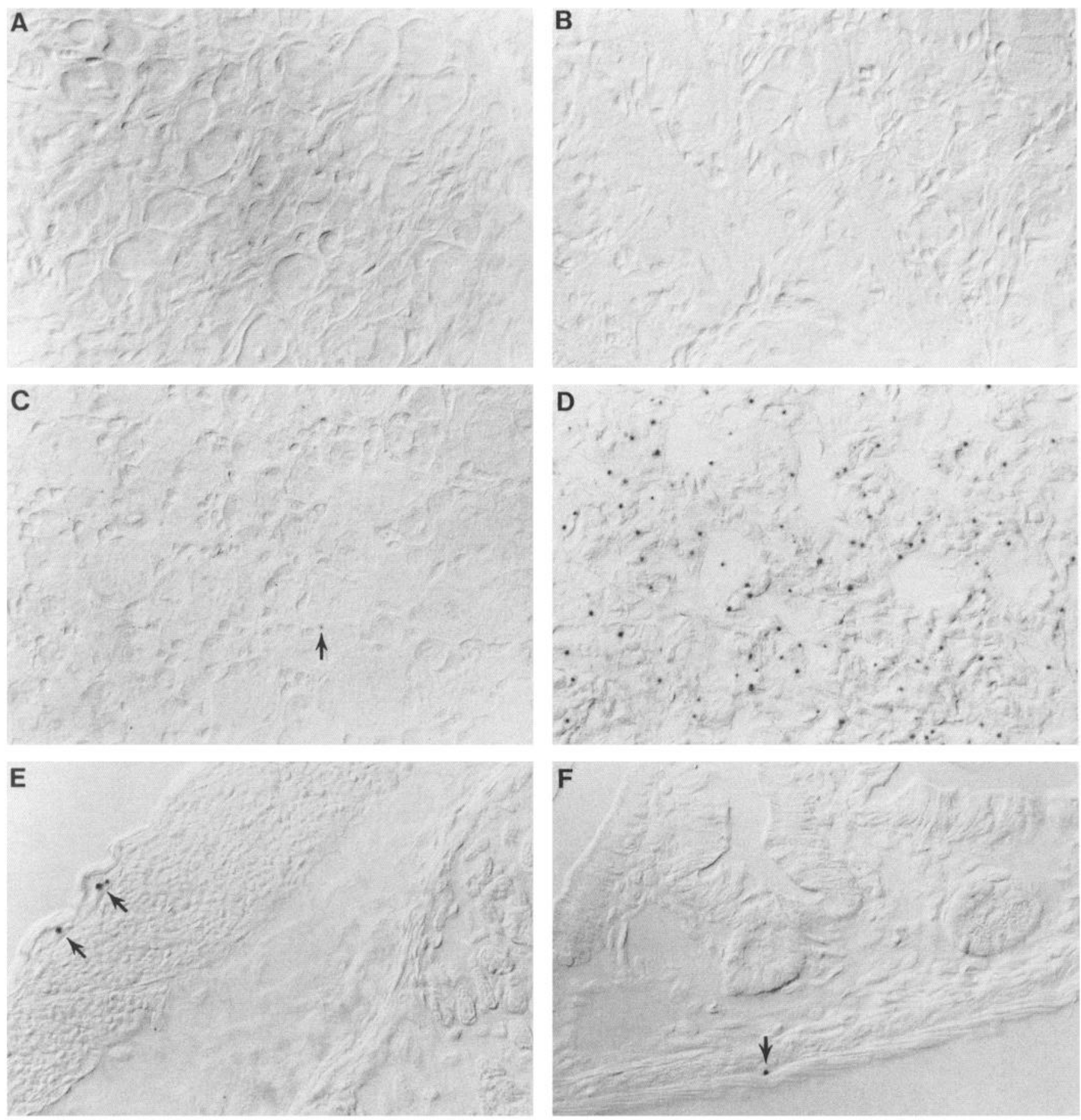

Figure 5. Transgene expression in the PNS. A, Section of the superior cervical ganglion of an adult $8.4 \mathrm{MNR} / a c Z$ mouse. LacZ activity is virtually undetectable. $B$, Section through the trigeminal ganglion from an adult 8.4MNRlac $Z$ mouse. Again, no transgene expression is seen. $C$, Section of a lumbar dorsal root ganglion from an adult $8.4 \mathrm{MNR}$ lacZ line 2 mouse. An extremely rare lightly staining neuron is indicated by an arrow. $D$, Section of adrenal gland from a 470MNRlac $Z$ line 11 mouse. Extensive lac $Z$ activity was found in the adrenal medulla. E, Transgene expression in myenteric neurons in the colon of an 8.4MNRlacZ line 2 mouse (arrows). LacZ activity was also found in myenteric neurons from the esophagus, stomach, duodenum, jejunum, and ileum of this line. $F$. Transgene expression in myenteric neurons (arrow) in the ileum from a $470 \mathrm{MNR}$ lac $Z$ line 11 animal. The pattern of expression in this line was virtually identical to that seen in the $8.4 \mathrm{MNRlacZ}$ lines.

rons and that these elements are contained in the first $470 \mathrm{bp}$ of 5' flanking sequence.

\section{Transgene expression in non-neural tissues}

To establish whether the $\mathrm{p} 75^{\mathrm{NGFR}}$ transgenes were appropriately regulated outside of the nervous system, we examined their ex- pression in a variety of non-neural tissues (see Table 3 for complete listing). Expression was detected only in the testes, kidney, pancreas, and pituitary. The adult testis normally expresses high levels of p75 NGFR mRNA (Ayer-Lievre et al., 1988), which is primarily found in Sertoli cells during specific stages of spermatogenesis (Parvinen et al., 1992). In concordance with these 


\begin{tabular}{|c|c|c|}
\hline Tissue & $\begin{array}{l}\text { 8.4MNRlac } Z \\
\text { lines }\end{array}$ & $\begin{array}{l}\text { 470MNRlac Z } \\
\text { lines }\end{array}$ \\
\hline Epididymis & $\mathrm{NA}^{\prime \prime}$ & $\mathrm{NA}^{\prime \prime}$ \\
\hline \multicolumn{3}{|l|}{ Gastrointestinal tract" } \\
\hline Esophagus & - & - \\
\hline Stomach & - & - \\
\hline Duodenum & - & - \\
\hline Jejunum & - & - \\
\hline Ileum & - & - \\
\hline Cecum & - & - \\
\hline Colon & - & - \\
\hline Heart & - & - \\
\hline Kidney & + & + \\
\hline \multicolumn{3}{|l|}{ Lacrimal gland } \\
\hline Liver & - & - \\
\hline Lung & - & - \\
\hline Lymph nodes & - & - \\
\hline \multicolumn{3}{|l|}{ Muscle } \\
\hline Diaphragm & - & - \\
\hline Gastrocnemius & - & - \\
\hline Ocular & - & - \\
\hline Ovary & - & - \\
\hline \multicolumn{3}{|l|}{ Pancreas } \\
\hline Exocrine & - & - \\
\hline Endocrine & + & + \\
\hline Parathyroids & - & - \\
\hline \multicolumn{3}{|l|}{ Pituitary } \\
\hline Anterior & + & + \\
\hline Posterior & - & - \\
\hline Seminal vesicle & - & - \\
\hline Spleen & - & - \\
\hline Submandibular gland & $\mathrm{NA}^{\prime \prime}$ & $\mathrm{NA}^{\prime \prime}$ \\
\hline Testis & + & + \\
\hline Thyroid & - & - \\
\hline Uterus & - & - \\
\hline \multicolumn{3}{|l|}{ Vasculature } \\
\hline Aorla & - & - \\
\hline Vena cava & - & - \\
\hline Arteries & - & - \\
\hline
\end{tabular}

"Endogenous neutral $\beta$-galactosidase activity was observed in the epididymis and submandibular gland, thereby compromising examination of these tissues. "Excludes myenteric neurons.

- Heart was positive only in 8.4MNRlac $Z$ line 2 mice; as this tissue was consistently negative in all other lineages, this is presumed to represent an integration site effect.

"See text for a precise description of localization in this tissue.

studies, we found very strong expression of both transgenes in the testes (Fig. 6A). Expression was confined to a subset of cells within the seminiferous tubules and examination of semithin plastic sections of testis stained for $\beta$-galactosidase activity showed these cells to be morphologically consistent with Sertoli cells (data not shown); we could not, however, rule out some expression by immature spermatocytic forms. These results indicate that both transgenes are appropriately regulated in testes and that the relevant regulatory elements are contained within the first 470 bp of $5^{\prime}$ flanking sequence.

In situ hybridization for $\mathrm{p} 75^{\mathrm{NCi} R \mathrm{R}} \mathrm{mRNA}$ shows prominent expression of this transcript in the developing nephrons of the embryonic kidney (Sariola et al., 1991; Wheeler and Bothwell, 1992), with $\mathrm{p} 75^{\mathrm{NGFR}}$ message being confined primarily to the mesangial cells of the glomerulus in the adult (Chesa et al., 1988). Interestingly, our transgenic mice did not precisely mimic either the adult or embryonic pattern of expression. In all five transgenic lines examined we found very intense histochemical activity in the calyx of the kidney, a region that contains primarily the loops of Henle (Fig. $6 B$ ). A lesser degree of staining was also present in the proximal convoluted tubule adjacent to the glomeruli (data not shown). One possible explanation for the presence of bacterial $\beta$-galactosidase in the renal calyx is that this represents enzyme that has been released from other sites in the body and taken up again during urinary filtration. This explanation seems unlikely, however, since one line (470MNRlac' $\angle$ line 6 ) demonstrated expression of reporter enzyme only in "stripes" of cells that presumably are clonally derived. These obscrvations suggest, rather, that additional elements not present in our transgenes are required for appropriate restriction of $\mathrm{p} 75^{\mathrm{NGl}-\mathrm{K}}$ expression in the kidney. Alternatively, we may be detecting this pattern of renal expression due to the increased sensitivity of the lac $Z$ reporter or because our transgene product is not subject to a form of posttranscriptional regulation that acts through elements in the native $\mathrm{p} 75^{\mathrm{NGFR}}$ mRNA.

We found prominent transgene expression in the pancreatic islets (Fig. $6 C$ ) and weak to moderate lac $Z$ activity in anterior pituitary cells (Fig. $6 D$ ). Although expression of $\mathrm{p} 75^{\mathrm{NCitR}}$ has not been previously described in the anterior pituitary, pancreatic islet cells respond to NGF by extending neurite-like processes (Polak et al., 1993) and express p75 ${ }^{\mathrm{NGFR}}$ (Scharfmann et al., $1994 a, b)$. It is currently unclear which of the pancreatic islet cell and anterior pituitary cell subpopulations express our transgenes. No differences were noted between the expression patterns of the 8.4MNRlac $Z$ and $470 \mathrm{MNR}$ lac $Z$ transgenes, again indicating that the relevant regulatory elements are within the first $470 \mathrm{bp}$ of $5^{\prime}$ flanking sequence.

\section{Trunsgene expression in axotomized peripheral nerve}

Surgical axotomy of peripheral nerves such as the sciatic has been found to result in a 50-fold increase in p $75^{\text {NGiFR }}$ mRNA by $7 \mathrm{~d}$ postaxotomy due to increased synthesis of this transcript by Schwann cells distal to the site of injury (Taniuchi et al., 1986, 1988; Heumann et al., 1987). Axotomy of the sciatic nerve has also been found to result in the reexpression of $\mathrm{p} 75^{\mathrm{NGitR}}$ by the spinal cord motoneurons contributing fibers to the sciatic nerve (Ernfors et al., 1989). To determine whether the 8.4MNRlacZ transgene was similarly responsive to PNS injury, unilateral sciatic axotomies were performed on male hemizygous mice from both of the 8.4MNRlac $Z$ lines and transgene expression was examined $1,3,7$, and $10 \mathrm{~d}$ postaxotomy. Serial sections through segments of nerve proximal and distal to the transection site as well as the contralateral nontransected nerve were examined. Transgene expression was undetectable in nontransected sciatic nerve (Fig. 7A). By 3-7 d postaxotomy, lac $Z$ activity had become detectable in clusters of spindle-shaped cells (presumably perincural cells or fibroblasts) adjacent to the site of axotomy in both the proximal and distal nerve segments (Fig. 7B). Unexpectedly, however, lacZ expression was undetectable in Schwann cells throughout the nerve segment distal to the site of axotomy (Fig. $7 C$ ). In addition, no expression was identified in either the L4 and L5 DRG or lumbar motoneurons in these axotomized mice (data not shown). The p $75^{\text {Nirr }}$ gene is also 

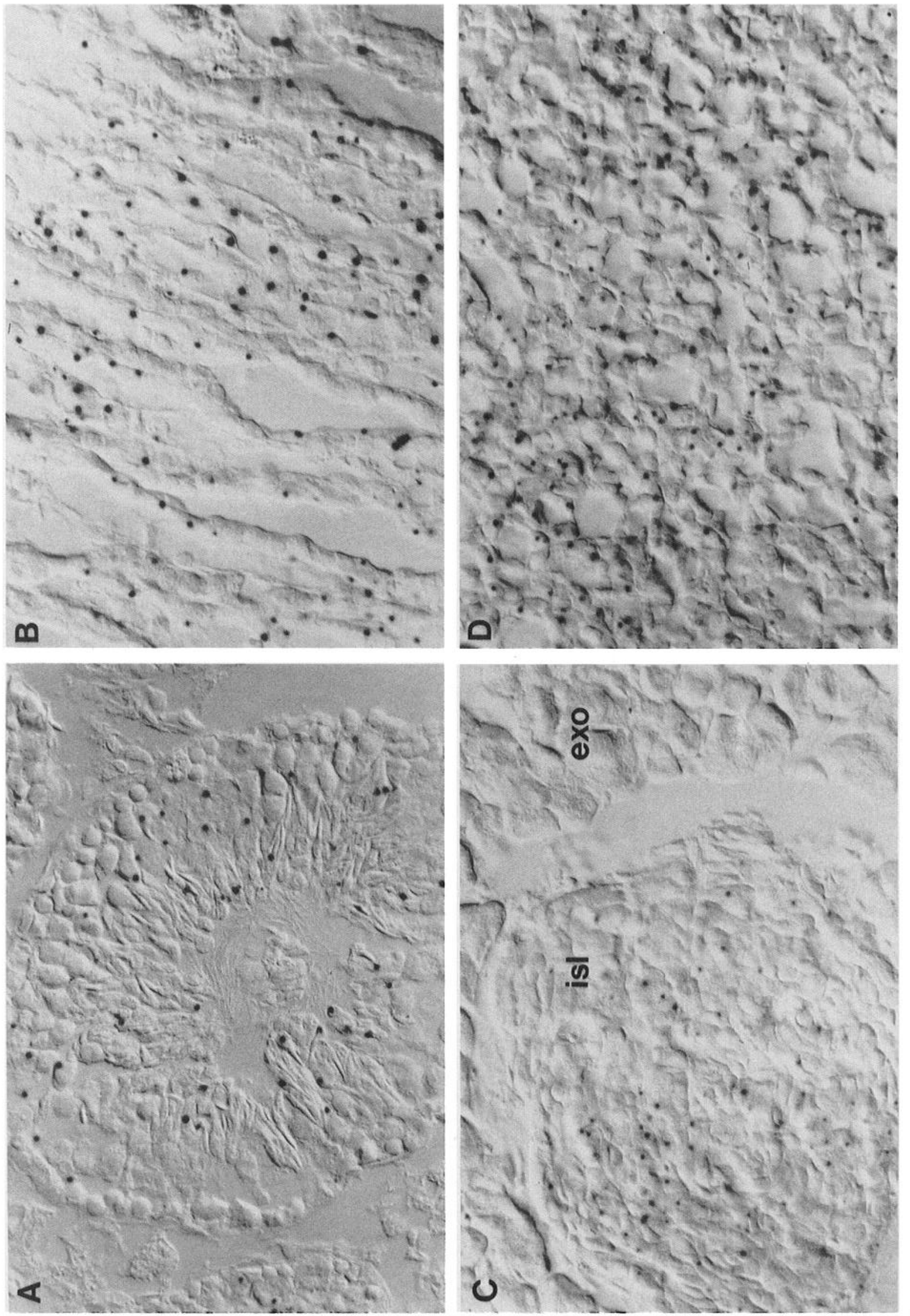

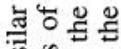

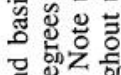

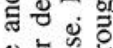
害岕

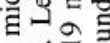
원 . 웡 跤主 可

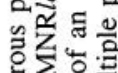
离守氞

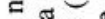

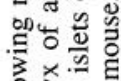

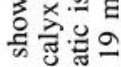
ส․ํํ. 온 뽏 $. \Xi . \Xi Z$

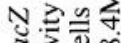
떠워 身氜 ส $\infty$ 년 ह

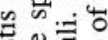

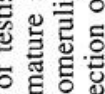
a on

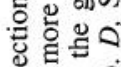
出 额 .50

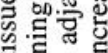
. 댕

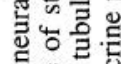

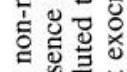
드융 동ํํํㅠ

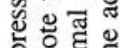

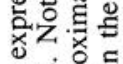
i $\dot{0}$ 인.

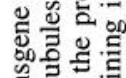
踏. No

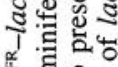
竞造

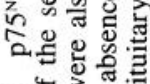
6 㟧等

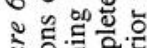
今. 

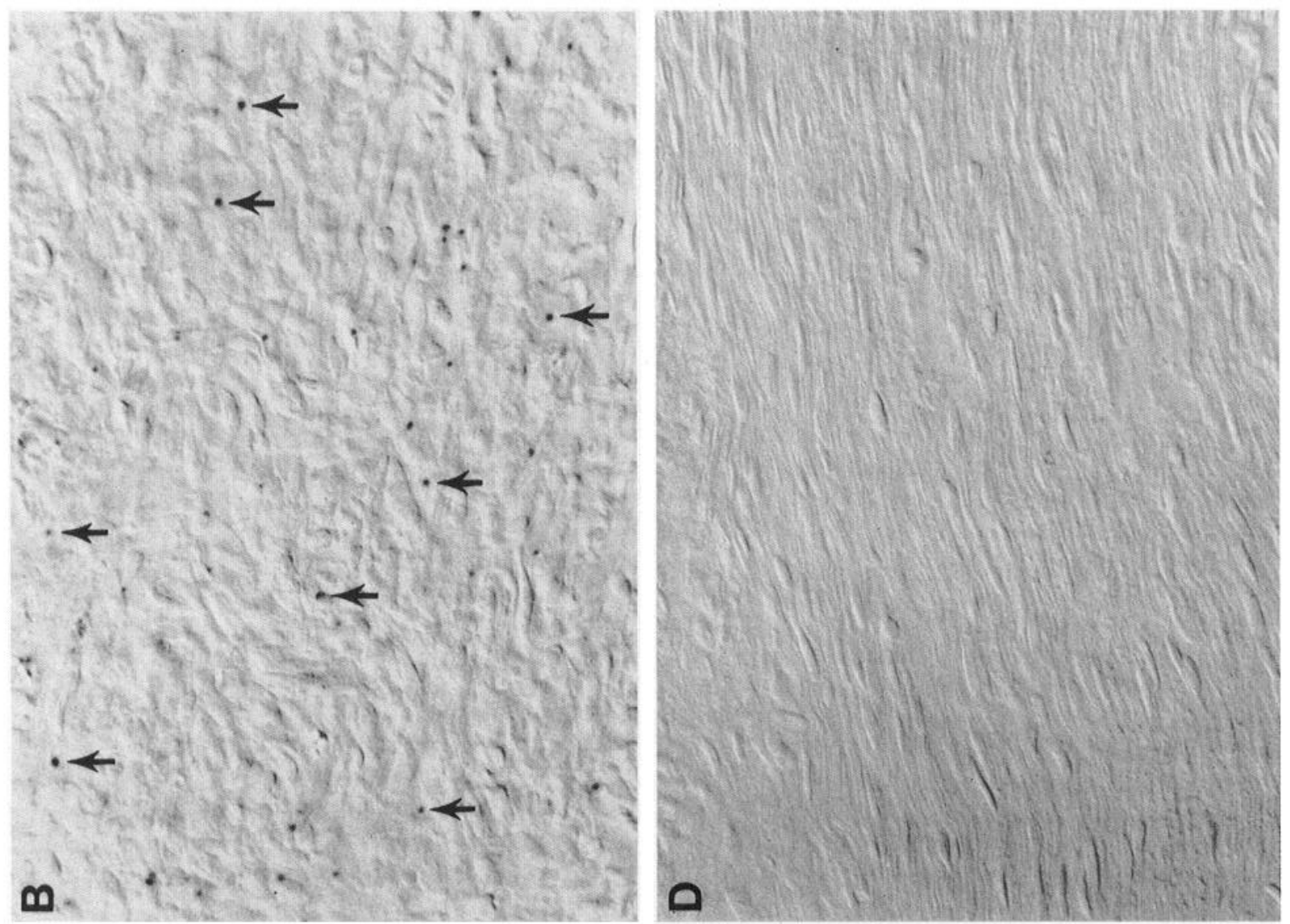

$\infty .9 .0$

응

ह

궁

要

Z

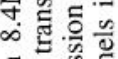

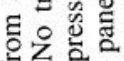

证言

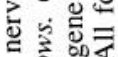

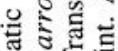

贾

要西

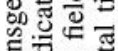

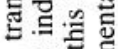

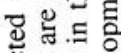

造 을

을.

曹

다워

엉. 명

造零哭

넝혀

政

解尔
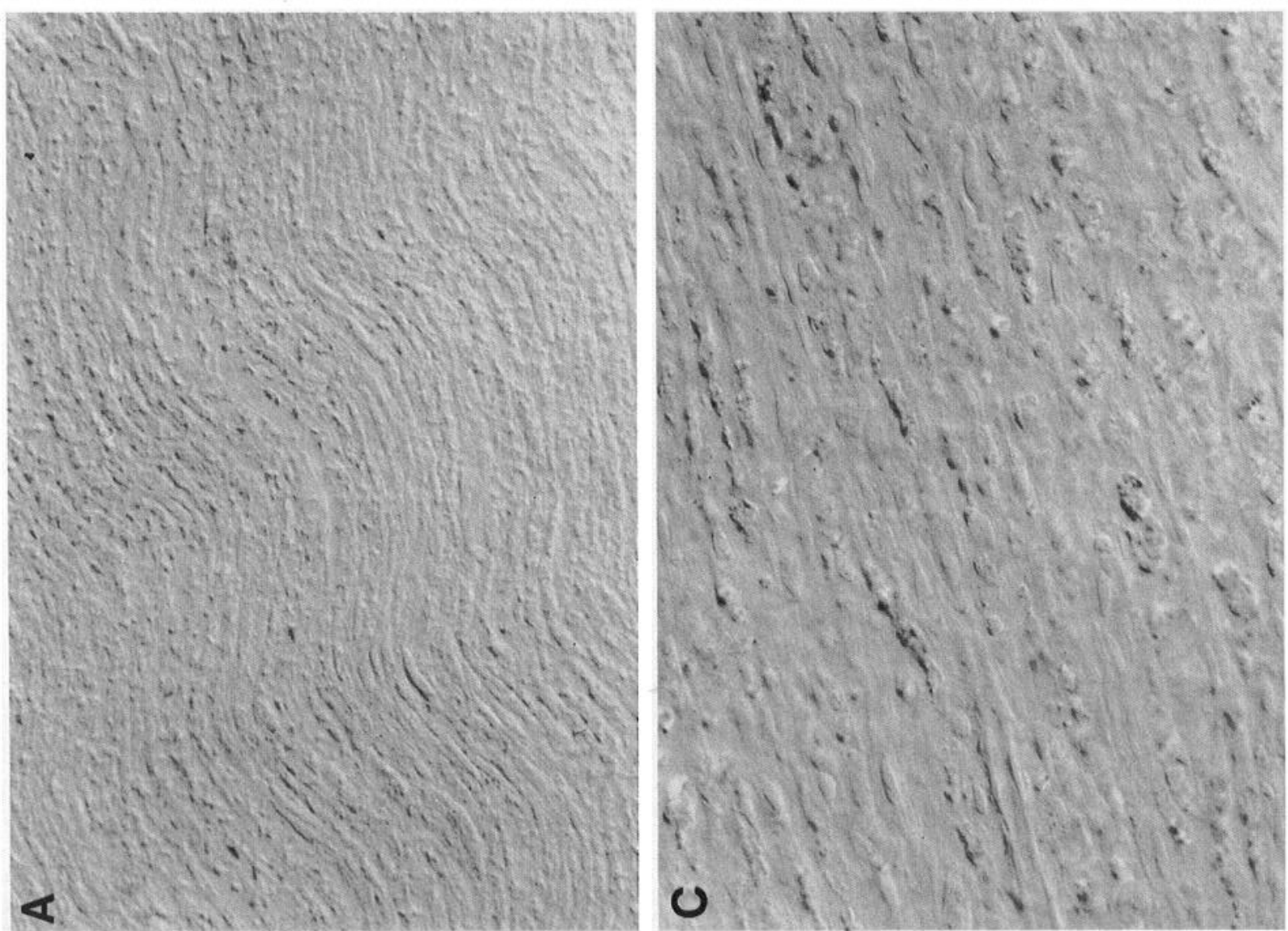

골.

ㄴㅇㅇㅝ

7 .

녕

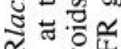

谷的高

运

$\infty$ 舟余它

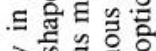

部

흥 峁

次家白

․․흘

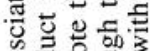

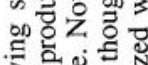

文公的

호융 정

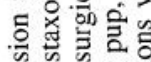

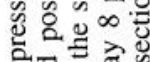

×० 정

的可

on

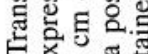

ख

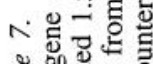

$\checkmark 50$

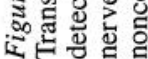


A

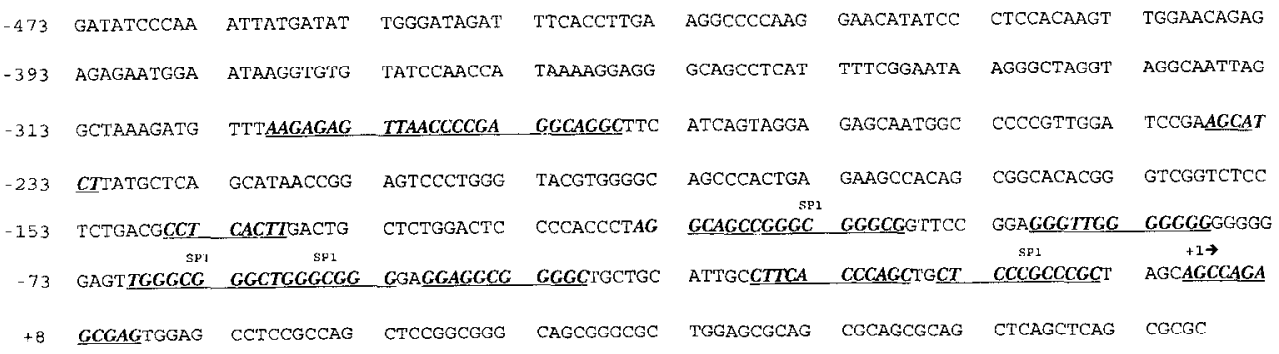

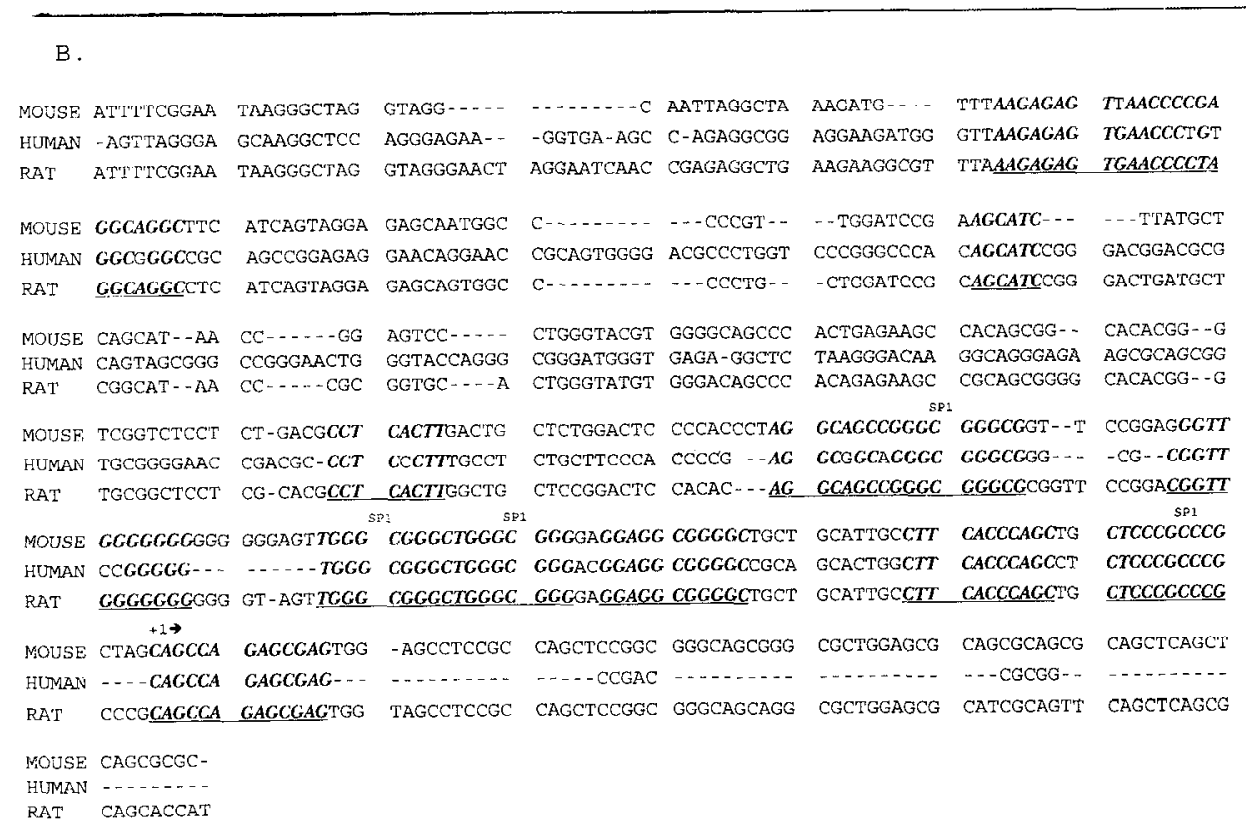

Figure 8. Phylogenetic footprinting of the p $75^{\text {Nitik }}$ promoter. $A$. Sequence of the 5 'flanking sequence and portion of mRNA $5^{\prime}$ untranslated region in the $470 \mathrm{MNR}$ lac $Z$ transgene. The transcription initiation site $(+1)$ is indicated by an arrow and is assigned based on Patil et al. (1990). The elements conserved in the promoters of all three mammalian p75 $5^{\text {NGF }}$ gentes are represented in underlined bold italics. SP1 consensus sequences $(G G G C G G)$ are as indicated. $B$. Alignment of the mouse, rat, and human $\mathrm{p} 75^{\text {NiriR }}$ promoters. Transcription initiation sites $(+I)$ are indicated by an arrow. Elements conserved among all three species are represented in underlined bold italirs. SP1 consensus sequences are as indicated. known to be expressed at high levels in Schwann cells during the first 3 postnatal weeks (Heumann et al., 1987). At postnatal day 8 , however, we found only very rare lac $Z$-positive cells in the sciatic nerve (Fig. $7 D$ ). We conclude that our transgenes lack at least some elements required for appropriate postaxotomy and developmental regulation in Schwann cells.

Comparison of $5^{\prime}$ flanking sequences from the mouse, human, and chicken genes

Having established that the promoter contained within the 470MNRlac $Z$ transgene was sufficient for expression in the CNS, retina, adrenal medulla, and myenteric neurons, we wished to identify candidate cis-acting regulatory elements within this DN $\Lambda$ fragment. As an initial step, the scquence of this fragment was determined. The sequence of the 82 nucleotides encoding a portion of the mRNA $5^{\prime}$ untranslated region and 470 bp of $5^{\prime}$ flanking sequence from this transgene is shown in Figure $8 \mathrm{~A}$. The promoter of the mouse $\mathrm{p} 75^{\mathrm{Nr} i \mathrm{R}}$ gene is highly $\mathrm{G}+\mathrm{C}$ rich (77\% over the first $115 \mathrm{bp}$; see below) and, like its human counterpart (Sehgal et al., 1988), has neither TATA or CCAAT consensus sequences (Fig. 8A). However, as is true for many genes that lack CCAAT and TATA boxes, several GGGCGG elements representing potential binding sites for the transcription factor SP1 (Dynan and Tjian, 1983; Dynan et al., 1986) are found within the first 115 bp of 5 ' flanking sequence.

As a means of identifying additional regulatory elements within the mouse promoter, the sequence of 957 nucleotides of $5^{\prime}$ flanking sequence from the human $\mathrm{p} 75^{\mathrm{Ni} i \mathrm{R}}$ gene was determined (see Materials and Methods and Fig. 8 legend for further details). These promoter sequences as well as the published sequence of the rat promoter (Metsis et al., 1992) were compared using both alignment (Corpet, 1988) and dot plot homology programs (PUSTELL matrix comparison, Intelligenetics) to produce a "phylogenetic footprint," a useful aid for the identification of potential regulatory elements. The greatest degree of homology was found between the mouse and rat $\mathrm{p} 75^{\mathrm{NG} F \mathrm{R}}$ promoters $(83 \%$ sequence identity over the 470 nucleotides of the mouse promoter), as would be expected from the relatively smaller evolutionary distance separating these species. Alignment with the more distantly related human promoter, however, eliminated many of the sequences conserved between rat and mouse as candidate regulatory elements. Ten elements of at least $6 \mathrm{bp}$ length were conserved among all three species (Fig. 8B). The majority of the conserved elements, including four consensus SP1 binding sites, were contained within the first 115 bp of the promoters. A second cluster of homology was identified, however, approximately 300 bp $5^{\prime}$ of the transcription initiation site.

\section{Discussion}

In an effort to define the molecular mechanisms responsible for genetic regulation during the development and regeneration of the nervous system, we and others have begun to characterize the cis-acting regulatory elements of the low-affinity NGF receptor locus, a model gene that may be of critical importance in 
these processes. Initial descriptions of the transeriptional regulation of this gene were enigmatic, as up to $3 \mathrm{~kb}$ of $5^{\prime}$ flanking sequence from the human gene demonstrated only constitutive activity in cultured cells (Sehgal et al., 1988), observations that were at variance with the exquisite cell-type specificity of the intact gene. It was subsequently found that a cosmid with $8 \mathrm{~kb}$ of $5^{\prime}$ flanking sequence, the entire human gene, and $7.5 \mathrm{~kb}$ of 3 flanking sequence precisely minicked expression of the endogenous gene, including expression in sensory and sympathetic ganglia and following sciatic axotomy (Patil et al,, 1990). We therefore hypothesized that additional regulatory elements necessary for appropriate expression are located between 3 and 8 $\mathrm{kb}$ upstream of the human transcription start site. After extensive analysis of comparable regions of the mouse $\mathrm{p} 75^{\mathrm{NG} \text { GR }}$ promoter in a variety of cell lines, however, we found no evidence for cell-type specificity conferred by these additional sequences. We also cloned internal fragments of the $\mathrm{p} 75^{\mathrm{NGirR}}$ gene (beginning in intron I and proceeding systematically through the entire gene to a point $4.5 \mathrm{~kb} 3^{\prime}$ of the gene) upstream of the $5^{\prime}$ flanking sequence in a $470 \mathrm{MNR}$ luciferase reporter in order to identify internal enhancers or silencers. Screening of these regions for enhancers or silencers functional in JS1 schwannoma, PC12 pheochromocytoma, or NIH3T3 fibroblasts was similarily unsuccessful (data not shown).

It has been noted that constructs inappropriately expressed in cell lines may be more properly regulated in transgenic mice (Dente et al., 1988; Zimmerman et al., 1990). We therefore designed two transgenes-one with an extensive $(8.4 \mathrm{~kb})$ portion of $5^{\prime}$ flanking sequence, the other with a presumably minimal promoter (470 bp) - and introduced them into the germline of mice. Despite the apparent constitutive nature of the $p 75^{\mathrm{NGFR}}$ promoter in cultured cells, we found that these sequences demonstrated a high degree of cell-type specificity in five lines of transgenic mice. The CNS was the most prominent site of transgene expression. With some minor exceptions, expression of the 8.4MNRlac $Z$ transgene was confined to neurons in specific structures in the brain previously found to express $p 75^{\text {NGFR }}$ including the basal forebrain, specific hypothalamic nuclei, the olfactory system, and cerebellum. Occasional structures not previously known to express p $75^{\mathrm{NaFR}}$ (e.g., lateral septal nuclei; Pioro and Cuello, 1990a) were found to express the 8.4MNR/ar 7 transgene. As these structures were consistently positive in multiple transgenic lines, it seems this discrepancy is not a result of integration site effects; instead, it may be due to the increased sensitivity of the lac $Z$ reporter or a requirement for restrictive transcriptional elements not present in the tested portion of 5' flanking sequence. Transcription of the 470MNRlac $Z$ construct was also confined to subpopulations of ependymal cells and neurons. The pattern of expression of this transgene differed from that of the 8.4MNRlac Z transgene, however, in that expression in the basal forebrain was lost. In addition, lac $Z$ activity was much more prominent in several structures (e.g., neocortex, hippocampus) not normally expressing p75 ${ }^{\mathrm{Nit}}$; it is not clear whether this latter finding is truly aberrant expression or is merely the result of the generally higher levels of activity of the $470 \mathrm{MNR}$ lac $Z$ transgene. These findings indicate that the first 470 nucleotides of $5^{\prime}$ flanking sequence from the mouse $\mathrm{p} 75^{\mathrm{N} \text { (it) }}$ gene contains regulatory elements capable of directing transcription in the brain as well as in the neural retina and several non-neural tissues. At least in the case of the basal forebrain, additional regulatory elements farther upstream are apparently necessary.
In contrast to the results obtained in the CNS, only minimal transgene activity was detected in several sensory (dorsal root) and sympathetic (coeliac, superior mesenteric, superior cervical) ganglia of neural crest origin that are classic sites of $\mathrm{p} 75^{\mathrm{NGFR}}$ expression. There was not, however, a general absence of transgene expression in the PNS as prominent lac $Z$ activity was detected in the chromaffin cells of the adrenal medulla and myenteric neurons. Regulation of our transgenes was apparently also aberrant in some peripheral neurons of non-neural crest origin as lac $Z$ expression was not found in the trigeminal ganglion (dual neural crest and placodal origin) or in the nodose ganglion (placodal origin). For reasons currently unclear, it seems that the p $75^{\text {NGFR }}$ locus is regulated differently in the adrenal medulla and myenteric neurons than in other PNS neurons and raises the question of whether the elements required for expression in these neurons may be similar, if not identical, to those utilized by CNS neurons. This further implies that different classes of PNS neurons regulate the expression of the $\mathrm{p} 75^{\mathrm{N}(\mathrm{iFR}}$ gene through distinct sets of regulatory elements.

Regulation of the $8.4 \mathrm{MNR}$ lacZ and $470 \mathrm{MNR}$ lacZ transgenes was aberrant in non-neural cells of the PNS as well. Surgical transection of the sciatic nerve results in a 50-fold elevation in p $75^{\text {NGFR }}$ mRNA in Schwann cells throughout the nerve segment distal to the site of axotomy by $7 \mathrm{~d}$ postlesioning (Taniuchi et al., 1986, 1988; Heumann et al., 1987). Although the temporal course of activation of our transgenes was virtually identical to that of the endogenous gene, lac $Z$ activity was confined to a population of spindle-shaped cells at the site of injury. It is currently unclear whether this expression is in a population of cells found only at the site of injury (e.g., perineurial cells proliferating at the site of injury) or whether cells immediately adjacent to the zone of injury are subject to regulatory influences not found throughout the distal nerve segment (e.g., diffusable factors). In either instance, it seems likely that appropriate responsiveness to injury requires additional regulatory elements not present in these transgenes.

We have shown that elements contained within the 5' flanking sequence from the mouse $\mathrm{p} 75^{\mathrm{N} \text { (it) }}$ gene, although capable of directing spatially appropriate expression in the CNS and nonneural tissucs, do not appcar to direct expression to appropriate sites in the PNS or to respond as expected to sciatic axotomy. If the regulatory elements of the human and mouse $\mathrm{p} 75^{\mathrm{NGFR}}$ genes are similarly positioned, then the $8.4 \mathrm{~kb}$ of $5^{\prime}$ flanking sequence from the mouse gene should have been functionally equivalent to the sequences from the human $\mathrm{p} 75^{\mathrm{NGFR}}$ cosmid previously found to be appropriately regulated in transgenic mice (Patil et al., 1990). Our findings suggest that additional regulatory elements are embedded within the body of the gene or in the $3^{\prime}$ flanking sequences. In this regard, our results are reminiscent of the recent report that basal and injury-responsive transcription of the peripherin gene is dependent upon intragenic elements (Belecky-Adams et al., 1991). An alternative possibility that must be considered, however, is that regulation of the p $75^{\mathrm{NGFR}}$ locus is not purely transcriptional and may involve posttranscriptional regulatory mechanisms such as mRNA stabilization. We have, in fact, identified several regions of unusually strong conservation in the untranslated regions of these mRNAs that may function as regulatory elements (data not shown).

In summary, we have demonstrated the ability of the mouse p75 NGFR promoter to direct expression of the bacterial lac $Z$ gene to appropriate neuronal subpopulations in the CNS. Our findings indicate that regulation of this locus in sensory and sympathetic 
neurons in the PNS is accomplished through the utilization of regulatory elements at least partially distinct from those responsible for CNS transcriptional control. Although the identification of these PNS regulatory elements is likely to be technically challenging due to the large size of the murine $\mathrm{p} 75^{\mathrm{NGFR}}$ gene $(35-$ $40 \mathrm{~kb}$ ), their characterization is of strong interest due to the light this may shed on how distinct neuronal populations differentially regulate the same gene. It is additionally possible that the various populations of CNS neurons expressing the $8.4 \mathrm{MNR}$ lacZ transgene may utilize different subsets of regulatory elements contained within this $8.4 \mathrm{~kb}$ of $5^{\prime}$ flanking sequence. Our identification of candidate regulatory elements within this region should be valuable in the identification of transcription factors binding to these sequences and a comparison of differential transcription factor expression in distinct neuronal populations.

\section{References}

Ayer-Lievre C, OIson L, Ebendal T, Hallbook F, Persson H (1988) Nerve growth factor mRNA and protein in the testis and epididymis of mouse and rat. Proc Natl Acad Sci USA 85:2628-2632.

Barde Y, Edgar D, Thoenen H (1982) Purification of a new neurotrophic factor from mammalian brain. EMBO J 1:549-553.

Belecky-Adams T, Wight DC, Kopchick JJ, Parysek LM (1991) Intragenic sequences are required for cell type-specific and injury-induced expression of the rat peripherin gene. $J$ Neurosci 39:231-234.

Berkemeier LR, Wilslow JW, Kaplan DR, Nikolics K, Goeddel DV, Rosenthal A (1992) Neurotrophin-5: a novel neurotrophic factor that activates trk and trkB. Neuron 7:857-866.

Bothwell M (1991a) Tissue localization of nerve growth factor and nerve growth factor receptors. Curr Top Microbiol Immunol 165:55-70.

Bothwell M (199/b) Keeping track of neurotrophin receptors. Cell 65: 915-918.

Carmignoto G, Comelli MC, Candeo P, Cavicchioli L, Yan Q, Merighi A, Maffei L (1991) Expression of NGF receptor and NGF receptor mRNA in the developing and adult rat retina. Exp Neurol 111:302311.

Carroll SL, Silos-Santiago I, Frese SE, Ruit KG, Milbrandt J, Snider WD (1992) Dorsal root ganglion neurons expressing trk are selectively sensitive to NGF deprivation in utero. Neuron 9:779-788.

Chao MV, Bothwell MA, Ross AH, Koprowski H, Lanahan AA, Buck CR, Sehgal A (1986) Gene transfer and molecular cloning of the human NGF receptor. Science 232:518-521.

Chesa PG, Wolfgang JR, Thomson TM, Old LJ, Melamed MR (1988) Immunohistochemical analysis of nerve growth factor receptor expression in normal and malignant tissues. J Histochem Cytochem 36:383389.

Corpet F (1988) Multiple sequence alignment with hierarchical clustering. Nucleic Acids Res 16:10881-10890.

Davies AM, Thoenen H, Barde Y-A (1986) The response of chick sensory neurons to brain-derived neurotrophic factor. J Neurosci 6:18971904.

Dente L, Ruther U, Tripodi M, Wagner EF, Cortese R (1988) Expression of human alpha 1 -acid glycoprotein genes in cultured cells and in transgenic mice. Genes Dev 2:259-266.

Drager UC, Edwards DL, Barnstable J (1984) Antibodies against filamentous components in discrete cell types of the mouse retina. J Neurosci 4:2025-2042.

Dynan WS, Tjian R (1983) The promoter-specific transcription factor Spl binds to upstream sequences in the SV40 early promoter. Cell 35: 79-87.

Dynan WS, Sazer S, Tijian R, Schimke RT (1986) Transcription factor $\mathrm{Sp} 1$ recognizes a DNA sequence in the mouse dihydrofolate reductase promoter. Nature 319:246-248.

Ernfors P. Henschen A, Olson L, Persson H (1989) Expression of nerve growth factor mRNA is developmentally regulated and increased after axotomy in rat spinal cord motoneurons. Neuron 2:1605-1613.

Feinberg A, Vogelstein B (1984) A technique for radiolabeling DNA restriction endonuclease fragments to high specific activity. Anal Biochem 67:15-28.

Friedman WJ, Olson L, Persson II (1991) Temporal and spatial expression of NGF receptor mRNA during postnatal rat brain development analyzed by in situ hybridization. Dev Brain Res 63:43-51.
Gage FH, Tuszynski MH, Chen KS, Fagan AM, Higgins GA (1991) Nerve growth factor function in the central nervous system. Curr Top Microbiol Immunol 165:71-93.

Gnahn H, Hetti F, Heumann R, Schwab ME, 'Thoenen H (1983) NGFmediated increase of choline acetyltransferase (ChAT) in neonatal rat forebrain: evidence for a physiological role of NGF in the brain? Dev Brain Res 9:45-52.

Goedert M, Otten U, Hunt SP, Bond A, Chapman D, Schlumpf M, Lichtensteiger N (1984) Binchemical and anatomical effects of antibodies against nerve growth factor on developing rat sensory ganglia. Proc Natl Acad Sci USA 81:1580-1584.

Hallbook F, Ibanez CF, Persson H (1991) Evolutionary studies of the nerve growth factor family reveal a novel member abundantly expressed in Xenopus ovary. Neuron 6:845-858.

Hefti $F$ (1986) Nerve growth factor promotes survival of septal cholinergic neurons after fimbrial transections. J Neurosci 6:2155-2162.

Hefti F, Hartikka J, Salvatierra A, Weiner WJ, Mash DC (1986) Localization of nerve growth factor receptors in cholinergic neurons of the human basal forebrain. Neurosci Lett 69:37-41.

Hempstead BL. Martin-Zanca D, Kaplan DR, Parada LF, Chao MV (1991) High-affinity NGF binding requires coexpression of the trk proto-oncogen and the low-affinity NGF receptor. Nature 350:678-683.

Heuer JG, Fatemie-Nainie S, Wheeler EF, Bothwell M (1990) Structure and developmental expression of the chicken NGF receptor. Dev Biol 137:287-304.

Heunann R, Lindholm D, Bandtlow C, Meyer M, Radeke MJ, Misko TP, Shooter EM, Thoenen H (1987) Differential regulation of mRNA encoding nerve growth factor and its receptor in rat sciatic nerve during development, degeneration and regeneration: role of macrophages. Proc Natl Acad Sci USA 84:8735-8739.

Hofer MM, Barde Y (1988) Brain-derived neurotrophic factor prevents neuronal death in vivo. Nature 331:261-262.

Hogan B, Constantini F, Lacy E (1986) Manipulating the mouse embryo: a laboratory manual. Cold Spring Harbor, NY: Cold Spring Harbor Laboratory.

Hohn A, Leibrock J, Bailey K, Barde Y-A (1990) Identification and characterization of a novel member of the ncrve growth factor/brainderived neurotrophic factor family. Nature 344:339-341.

Holtzman DM, Li Y, Parada LF, Kinsman S, Chen C-K, Valletta JS, Zhou J, Long JB, Mobley WC (1992) p140trk mRNA marks NGF-responsive forebrain neurons: evidence that trk gene expression is induced by NGF. Neuron 9:465-478.

Hosang M, Shooter EM (1985) The internalization of nerve growth factor by high-affinity receptors on pheochromocytoma PC12 cells. EMBO J 6:1197-1202.

Johnson D, Lanahan A, Buck CR, Sehgal A, Morgan C, Mercer E, Bothwell M, Chao M (1986) Expression and structure of the human NGF receptor. Cell 47:545 554 .

Kaplan DR, Hempstead BL, Martin-Zanca D, Chao MV, Parada LF (1991a) The trk proto-oncogene product: a signal transducing receptor for nerve growth factor. Science 252:554-558.

Kaplan DR, Martin-Zanca D, Parada LF (1991b) Tyrosine phosphorylation and tyrosine kinase activity of the trk proto-oncogene product induced by NGF. Nature 350:158-160.

Klein R, Jing S, Naduri V, O'Rourke E, Barbacid M (1991) The trk proto-oncogene encodes a receptor for nerve growth factor. Cell 65: 189-197.

Koh S, Loy R (1989) Localization and development of nerve growth factor-sensitive rat basal forebrain neurons and their afferent projections to hippocampus and neocortex. J Neurosci 9:2999-3018.

Koh S, Oyler GA, Higgins GA (1989) Localization of nerve growth factor receptor messenger RNA and protein in the adult rat brain. Exp Neurol 106:209-221.

Landreth GE, Shooter EM (1980) Nerve growth factor receptors on PC12 cells: ligand-induced conversion from low- to high-affinity states. Proc Natl Acad Sci USA 77:4751-4755.

Large TH, Weskamp G, Helder JC, Radeke MJ, Misko TP, Shooter EM, Reichardt LF (1989) Structure and developmental expression of the nerve growth factor receptor in the chicken central nervous system. Neuron 2:1123-11.34.

Lax I, Burgess WH, Bellot F, Ullrich A, Schlessinger J, Givol D (1988) Localization of a major receptor-binding domain for epidermal growth factor by affinity labeling. Mol Cell Biol 8:1831-1834.

Lee K-F, Li E, Huber LJ, Landis SC, Sharpe AH, Chao MV, Jaenisch R (1992) Targeted mutation of the gene encoding the low affinity NGF 
receptor p75 leads to deficits in the peripheral sensory nervous system. Cell 69:737-749

Leibrock J, Lottspeich F, Hohn A, Hofer M, Hengerer B, Masiakowski P, Thoenen II, Barde Y-A (1989) Molccular cloning and expression of brain-derived neurotrophic factor. Nature $341: 149-152$.

Levi-Montalcini R (1987) The nerve growth factor 35 years later. Science 237:1154-1162.

Lindsay RM, Rohrer H (1985) Placodal sensory neurons in culture: nodose ganglion neurons are unresponsive to NGF, lack NGF receptors but are supported by a liver-derived neurotrophic factor. Dev Biol 112: $30-48$.

Loeb DM, Maragos J, Martin-Zanca D, Chao MV, Parada LF, Greene LA (1992) The trk proto-oncogene rescues NGF responsiveness in mutant NGF-nonresponsive PC12 cell lines. Cell 66:961-966.

Macdonnell PC, Tolson N, Yu MW, Guroff G (1977) The de novo synthesis of tyrosine hydroxylase in vitro: the effects of nerve growth factor. J Neurochem 28:843-849.

Maisonpierre PC, Belluscio L, Squinto S, Ip NY, Furth ME, Lindsay RM, Yancopoulos GD (1990) Neurotrophin-3: a neurotrophic factor related to NGF and BDNF. Science 247:1446-145!.

Max SR, Rohrer H, Otten U, Thoenen H (1978) Nerve growth factormediated induction of tyrosine hydroxylase in the rat superior ganglia in vitro. J Biol Chem 253:8013-8015.

Meakin SO, Shooter EM (1992) The nerve growth factor family of receptors. Trends Neurosci 15:323-331.

Mercer EH, Hoyle GW, Kapur RP, Brinster RL, Palmiter RD (1991) The dopamine beta-hydroxylase gene promoter directs expression of $E$. coll $l a c Z$ to sympathetic and other neurons in adult transgenic mice. Neuron 7:703-716.

Metsis M, Timmusk T, Allikmets R, Saarma M, Persson H (1992) Regulatory elements and transcriptional regulation by testosterone and retinoic acid of the rat nerve growth factor receptor promoter. Gene 121 : 247-254.

Mobley WC, Rutkowski JL, Tennekoon GI, Buchanan K, Johnson MV (1985) Choline acetyltransferase activity in striatum of neonatal rats increased by nerve growth factor. Science 229:284-287.

Otten U, Schwab M, Gagnon C, Thoenen H (1977) Selective induction of tyrosine hydroxylase and dopamine beta-hydroxylase by nerve growth factor: comparison between adrenal medulla and sympathetic ganglia of adult and newborn rats. Brain Res 133:291-303.

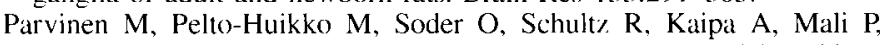
Toppari J, Hakovirta H, Lonnerberg P, Ritzen EM, Ebendal T, Olson L, Hokfelt T, Persson $H$ (1992) Expression of beta nerve growth factor and its receptor in rat seminiferous epithelium: specific function at the onset of meiosis. J Cell Biol 1 17:629-641.

Patil N, Lacy E, Chao MV (1990) Specific neuronal expression of human NGF receptors in the basal forebrain and cerebellum of transgenic mice. Neuron 2:437-447.

Pioro EP, Cuello AC (1990a) Distribution of nerve growth factor receptor-like immunoreactivity in the adult rat central nervous system. Effect of colchicine and correlation with the cholinergic system-I. Forebrain. Neuroscience 34:57-87

Pioro EP, Cuello AC (1990b) Distribution of nerve growth factor receptor-like immunoreactivity in the adult rat central nervous system. Effect of colchicine and correlation with the cholinergic system-II. Brainstem, cerebellum and spinal cord. Neuroscience 34:89-110.

Polak M, Scharfmann R, Seilheimer B, Eisenbarth G, Dressler D, Verma IM, Potter H (1993) Nerve growth factor induces neuron-like differentiation of an insulin-secreting pancreatic beta cell line. Proc Natl Acad Sci USA 90:5781-5785.

Pryor JC, Horigome K, Johnson EM Jr (1992) Mast cells express trk but not low affinity nerve growth factor receptor. Soc Neurosci Abstr. 18:950.

Rabizadeh S, Oh J, Zhong L, Yang J, Bitler CM, Butcher LL, Bredesen DE (1993) Induction of apoptosis by the Iow-affinity NGF receptor Science 261:345-348.

Radeke MJ, Feinstein SC (1991) Analytical purification of the slow, high affinity $\mathrm{NGF}$ receptor: identification of a novel $135 \mathrm{kd}$ polypeptide. Neuron 7:141-150.

Radeke MJ, Misko TP, Hsu C, Herzenberg LA, Shooter EM (1987) Gene transfer and molecular cloning of the rat nerve growth factor receptor. Nature 325:593-597.

Rodriguez-Tebar A, Dechant G, Barde Y-A (1990) Binding of brain- derived neurotrophic factor to the nerve growth factor receptor. Neuron $4: 487-492$

Rosenthal A, Goeddel GV, Nguyen T, Lewis M, Shih A, Laramee GR, Nikolics K. Winslow JW (1990) Primary structure and biological activity of a novel human neurotrophic factor. Neuron 4:767-773.

Sanes JR, Rubenstein JLR, Nicolas J-F (1986) Use of a recombinant retrovirus to study post-implantation cell lineage in mouse embryos. EMBO J 5:3133-3142.

Sanger F, Nicklen S, Coulson AR (1977) DNA sequencing with chainterminating inhibitors. Proc Natl Acad Sci USA 74:5463-5467.

Sariola H, Saarma M, Sainio K, Arumae U, Palgi J, Vaahtokari A, Thesleff I, Karavanov A (1991) Dependence of kidney morphogenesis on the expression of nerve growth factor receptor. Science 254:571-573.

Scharfmann R, Atouf F, Tazi A, Czernichow P (1994a) Growth hormone and prolactin regulate the expression of nerve growth factor receptors in INS-1 cells. Endocrinology 134:2321-2328.

Scharfmann R, Tazi A, Polak M, Kanaka C, Czernichow P (1994b) Expression of functional nerve growth factor receptors in pancreatic B-cell lines and fetal rat islets in primary culture. Diabetes 42:18291836

Schecter AL. Bothwell MA (1981) Nerve growth factor receptors on PCl2 cells: evidence for two receptor classes with differing cytoskeletal association. Cell 24:867-874.

Sehgal A, Patil N, Chao M (1988) A constitutive promoter directs expression of the nerve growth factor receptor gene. Mol Cell Biol. $8: 3160-3167$

Springer JE, Koh S, Tayrien MW, Loy R (1987) Basal forebrain magnocellular neurons stain for nerve growth factor receptor: correlation with cholinergic cell bodies and effects of axotomy. I Neurosci Res 17:111-118.

Squinto SP, Stitt TN, Aldrich TH, Davis S, Bianco SM, Radriejewski C, Glass DJ, Masiakowski P, Furth ME, Valenzuela DM, DiStefano PS, Yancopoulos GD (1991) trkB encodes a functional receptor for brainderived neurotrophic factor and neurotrophin-3 but not nerve growth lactor. Cell 65:885-893.

Sutter A, Riopella RJ, Harris-Warrick RM, Shooter EM (1979) Nerve growth factor receptors: characterization of two distinct classes of binding sites on chick embryo sensory ganglia cells. J Biol Chem 254: $5972-5982$

Taniuchi M, Clark HB, Johnson EM (1986) Induction of nerve growth factor in Schwann cells after axotomy. Proc Natl Acad Sci USA 83: 4094-4098.

Taniuchi M, Clark HB, Schweitzer JB, Johnson EM Jr (1988) Expression of nerve growth factor receptors by Schwann cells of axotomized peripheral nerves: ultrastructural location, suppression by axonal contact and binding properties. J Neurosci 8:664-681

Thoenen H, Barde Y-A (1980) Physiology of nerve growth factor. Physiol Rev 60:1284-1335.

Vogelstein B, Gillespie D (1979) Preparative and analytical purification of DNA from agarose. Proc Natl Acad Sci USA 76:615-619.

Wanaka A, Johnson EM Jr (1990) Developmental study of nerve growth factor receptor mRNA expression in the postnatal rat cerebellum. Dev Brain Res 55:288-292.

Weskamp G, Reichardt LF (1991) Evidence that biological activity of NGF is mediated through a novel subclass of high affinity receptors. Neuron 6:649-663.

Wheeler EF, Bothwell M (1992) Spatiotemporal patterns of expression of NGF and the low-affinity NGF receptor in rat embryos suggest functional roles in tissue morphogenesis and myogenesis. $J$ Neurosci 12:930-945.

Williams LR, Varon S, Peterson GM, Wictorin K, Fischer W, Bjorklund A, Gage FH (1986) Continuous infusion of nerve growth factor prevents basal forebrain neuronal death after fimbria fornix transection. Proc Natl Acad Sci USA 83:9231-9235.

Yan Q, Johnson EM Jr (1989) Immunohistochemical localization and biochemical characterization of nerve growth factor receptor in adult rat brain. J Comp Neurol 290:585-598.

Zack DJ, Bennett J, Wang Y, Davenport C, Klaunberg B, Gearhart J, Nathans J (1991) Unusual topography of bovine rhodopsin promoterlac $Z$ fusion gene expression in transgenic mouse retinas. Neuron 6:187-199.

Zimmerman K, Legouy E, Stewart V, Depinho R, Alt FW (1990) Differential regulation of the $\mathrm{N}$-myc gene in transfected cells and transgenic mice. Mol Cell Biol 10:2096-2103. 